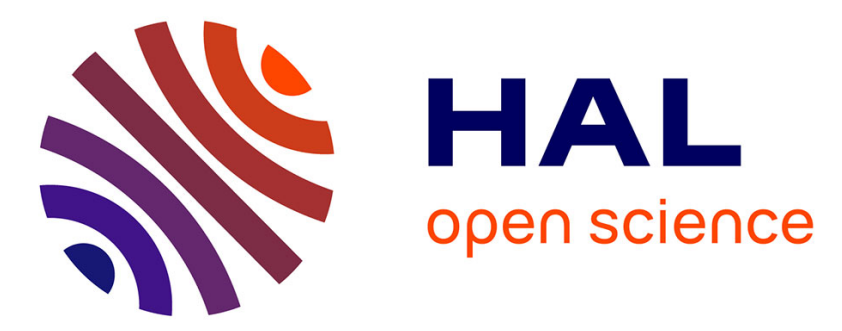

\title{
Aerosol-cloud interactions in the NASA GMI: model development and indirect forcing assessments
}

N. Meskhidze, R. E. P. Sotiropoulou, A. Nenes, J. Kouatchou, B. Das, J. M. Rodriguez

\section{- To cite this version:}

N. Meskhidze, R. E. P. Sotiropoulou, A. Nenes, J. Kouatchou, B. Das, et al.. Aerosol-cloud interactions in the NASA GMI: model development and indirect forcing assessments. Atmospheric Chemistry and Physics Discussions, 2007, 7 (5), pp.14295-14330. hal-00303123

\section{HAL Id: hal-00303123 \\ https://hal.science/hal-00303123}

Submitted on 9 Oct 2007

HAL is a multi-disciplinary open access archive for the deposit and dissemination of scientific research documents, whether they are published or not. The documents may come from teaching and research institutions in France or abroad, or from public or private research centers.
L'archive ouverte pluridisciplinaire HAL, est destinée au dépôt et à la diffusion de documents scientifiques de niveau recherche, publiés ou non, émanant des établissements d'enseignement et de recherche français ou étrangers, des laboratoires publics ou privés. 


\section{Aerosol-cloud interactions in the NASA GMI: model development and indirect forcing assessments}

N. Meskhidze ${ }^{1,{ }^{\star}}$, R. E. P. Sotiropoulou ${ }^{1}$, A. Nenes ${ }^{1,2}$, J. Kouatchou ${ }^{3}$, B. Das ${ }^{3}$, and J. M. Rodriguez ${ }^{3}$

${ }^{1}$ School of Earth and Atmospheric Sciences, Georgia Institute of Technology, Atlanta, GA, USA

${ }^{2}$ Schools of Chemical \& Biomolecular Engineering, Georgia Institute of Technology, Atlanta, GA, USA

${ }^{3}$ NASA Goddard Space Flight Center, Greenbelt, Washington, USA

"now at: School of Marine Earth and Atmospheric Sciences, North Carolina State University, Raleigh, NC, USA

Received: 6 September 2007 - Accepted: 20 September 2007 - Published: 9 October 2007

Correspondence to: A. Nenes (nenes@eas.gatech.edu)

Aerosol-cloud interactions in the

NASA GMI

N. Meskhidze et al.

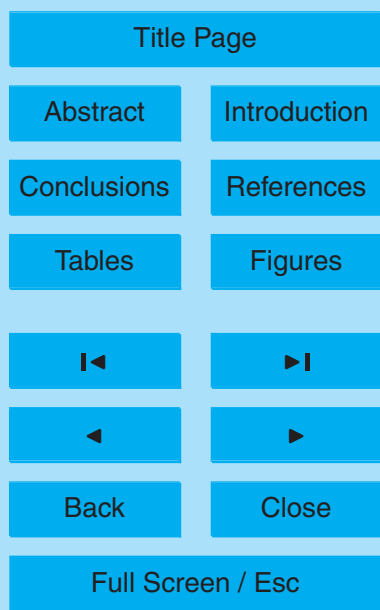

Printer-friendly Version

Interactive Discussion 


\section{Abstract}

This study uses the NASA Global Modeling Initiative (GMI) 3-D chemical transport model (CTM) for assessments of indirect forcing and its sensitivity to the treatment of aerosol, aerosol-cloud interactions and meteorological fields. Three different meteoro-

5 logical datasets from NASA Data Assimilation Office (DAO), NASA finite volume GCM (FVGCM) and the Goddard Institute for Space Studies version II' (GISS II') GCM were used. GMI is ideal for this study as different model components (such as meteorological fields and chemical mechanisms) can easily be interchanged under the same model framework to capture the first aerosol indirect effect (AIE), and its sensitivity 10 to parameterizations and meteorological fields. Cloud droplet number concentration was calculated by implementing both diagnostic and physically based droplet parameterizations. Derived cloud properties, such as cloud optical thickness and effective radius were compared with the remotely sensed data from Moderate Resolution Imaging Spectroradiometer (MODIS). GMI was able to capture the spatial variability and the 15 land-ocean contrast observed in the satellite record. Depending on the meteorological field and droplet parameterization used, the annual mean first AIE ranged from -0.99 to $-1.48 \mathrm{~W} \mathrm{~m}^{-2}$. It is found that, roughly $80 \%$ of the variation is attributed to changes in the meteorology (primarily from variations in liquid water path), while the remaining $20 \%$ is attributed to different cloud droplet parameterizations.

\section{Introduction}

The interactions of aerosol, cloud and radiation (known as the aerosol indirect effect, AIE), remains one of the major uncertainties in assessments of anthropogenic climate change (e.g., Intergovernmental Panel on Climate Change (IPCC), 2001, 2007). AIE estimates are done using a Global Climate Model (GCM) with an online aerosol simulation and explicit aerosol-cloud coupling to predict changes in cloud properties from anthropogenic activities; climate impacts (forcing) are then estimated. AIE estimates

\section{Aerosol-cloud interactions in the NASA GMI}

N. Meskhidze et al.

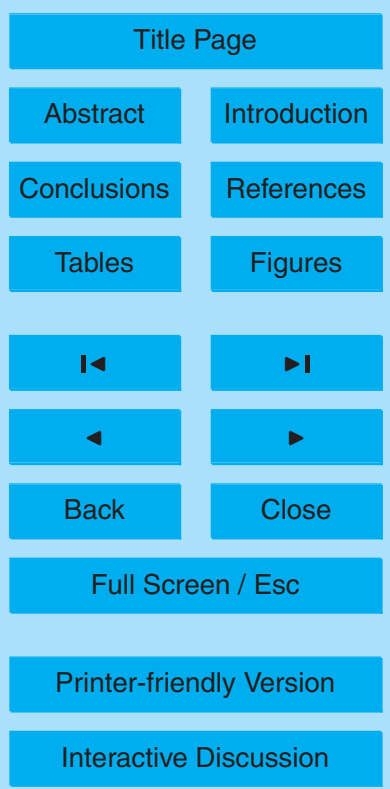


from direct changes in cloud albedo vary from -0.5 to $-1.9 \mathrm{~W} \mathrm{~m}^{-2}$ and from -0.3 to $-1.4 \mathrm{~W} \mathrm{~m}^{-2}$ for feedbacks on precipitation and cloud structure (e.g., Kiehl et al., 2000; Lohmann et al., 2000; Ghan et al., 2001; Jones et al., 2001; Rotstayn and Penner, 2001; Chuang et al., 2002; Menon et al., 2002; Kristjánsson, 2002; Lohmann and Fe5 ichter, 2005; Suzuki et al., 2004; Chen and Penner, 2005). Recent estimates of AIE summarized by Intergovernmental Panel on Climate Change (IPCC) (2007) suggest that, although subject to substantial uncertainty, the magnitude of AIE is potentially comparable to greenhouse warming. Therefore, constraining AIE is an important step for an accurate estimation of anthropogenic climate change.

An important step towards constraining AIE is attributing the contribution of aerosol representation, cloud droplet parameterizations, emission scenarios and meteorological fields to indirect forcing uncertainty. Comparison between outputs of different GCMs is challenging, as differences in cloud properties may be a convolution of uncertainties other than that arising from e.g., meteorological fields. This issue can be resolved if assessments are done within the same modeling framework; the NASA Global Modeling Initiative (GMI) is ideally suited for this purpose, as it is highly modular, allowing easy interchange of different model components (e.g., meteorological fields, chemical mechanisms, aerosol microphysics and droplet parameterizations) while maintaining all other components of the model identical. This study focuses on using GMI to obtain assessments of AIE and its sensitivity to three meteorological fields and two droplet parameterizations.

\section{Framework description}

\subsection{The NASA Global Modeling Initiative (GMI)}

The NASA GMI (https://gmi.gsfc.nasa.gov/gmi.html) is a state-of-the-art modular 3-D

\section{ACPD}

7, 14295-14330, 2007

Aerosol-cloud interactions in the NASA GMI

N. Meskhidze et al.

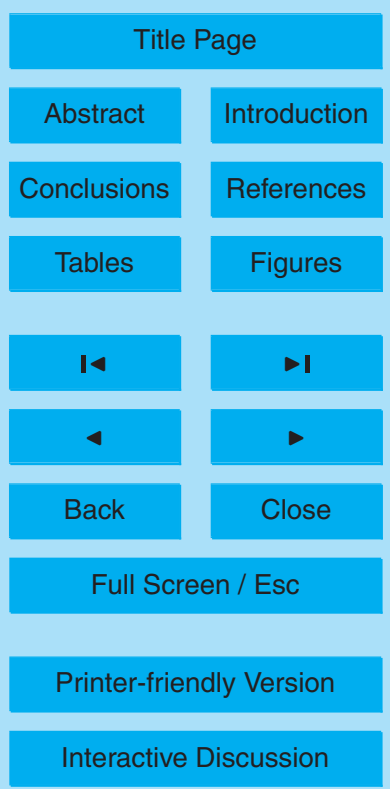
tions for impact assessment studies. The GMI-CTM exists in separate tropospheric, 
stratospheric, aerosol and combined stratospheric-tropospheric versions. The detailed description of the framework can be found in Rotman et al. (2001) and Considine et al. (2005). The GMI aerosol model used in this study was contributed by Liu et al. (2005) and coupled to the GMI-CTM advection core. The aerosol module includes primary

emissions, chemical production of sulfate in clear air and in-cloud aqueous phase, gravitational sedimentation, dry deposition, wet scavenging in and below clouds, and hygroscopic growth. Model inputs include $\mathrm{SO}_{2}$ (fossil fuel and natural), DMS, $\mathrm{H}_{2} \mathrm{O}_{2}$, black carbon (from biomass burning and natural sources), organic carbon (fossil fuel, biomass burning, and natural), mineral dust (4 size bins), and sea salt (4 size bins).

10 The model time step for chemistry is one hour.

The meteorological data used in this work were taken from the NASA Data Assimilation Office (DAO), the NASA finite volume GCM (FVGCM) and the Goddard Institute for Space Studies version II' (GISS II') GCM. Each of the archived meteorological fields spans one year. DAO represents the period from 1 March 1997 to 28 February 1998.

15 FVGCM fields were obtained from a one-year realization of the GCM in free-running mode, forced by 1994 sea surface temperatures. GISS fields are one-year simulations from the GISS II' GCM (Rind and Lerner, 1996; Koch and Rind, 1998) which includes a slab (Q-flux) ocean model. The horizontal resolution in all simulations is $4^{\circ}$ latitude by $5^{\circ}$ longitude. The vertical resolution varies between datasets; DAO field has 46 vertical levels (from surface to $4.710^{-5} \mathrm{hPa}$ ); FVGCM and GISS II' fields, 42 and 23 vertical layers, respectively (from surface to $1.710^{-2} \mathrm{hPa}$ ). Meteorological information from the DAO meteorological field were updated at 6-h intervals while from FVGCM and GISS II' datasets at 3-h intervals, respectively.

\subsection{The GMI aerosol-cloud scheme}

\subsubsection{Cloud fraction calculation}

Two types of clouds exist in GMI: convective and stratiform. Clouds are allowed to form in any model layer (with the exception of the layer nearest to the surface to constrain

\section{Aerosol-cloud interactions in the NASA GMI}

N. Meskhidze et al.

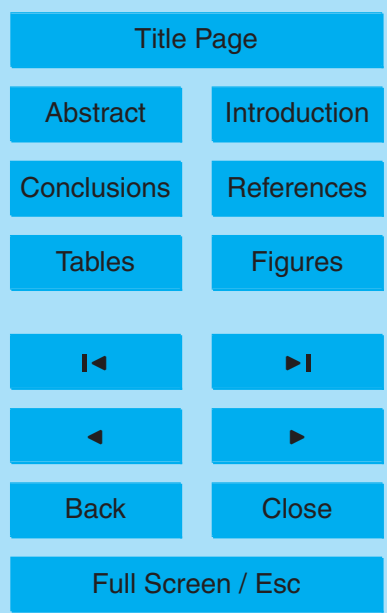

Printer-friendly Version

Interactive Discussion 
wet deposition). Large scale cloud fraction, $C_{L S}$, is diagnosed based on large-scale relative humidity $(\mathrm{RH})$ following Sundqvist et al. (1989):

$c_{L S}=1-\sqrt{1-\frac{\mathrm{RH}-\mathrm{RH}_{c}}{1-\mathrm{RH}_{C}}}$

where $\mathrm{RH}_{C}$ is the threshold relative humidity for condensation specified as a function of 5 pressure (Xu and Krueger, 1991). For convective cloud fraction, $C_{C}$, a parameterization with convective mass flux (Xu and Krueger, 1991) was adopted:

$C_{c}= \begin{cases}c_{0}+c_{1} \log \left(M_{C}\right)+c_{2}\left(\log \left(M_{c}\right)\right)^{2} & \text { if } M_{c}>0.01 \mathrm{hPa} \mathrm{h}^{-1} \\ 0 & \text { otherwise }\end{cases}$

where $M_{c}$ is the convective mass flux, and the coefficients $c_{0}, c_{1}, c_{2}$ are given as a function of pressure. Total cloud fraction, $C$, in each grid cell is obtained from the o combination of the large scale cloud fraction and convective cloud fraction by Feng et al. (2004), which has shown to adequately reproduce the observed global distribution of liquid water path,

$C=1-\left(1-C_{L S}\right)\left(1-C_{C}\right)$

Following Hack (1998), the cloud liquid water content (LWC) is vertically distributed using a prescribed cloud liquid water density profile, $\rho_{l}(z)$, (Kiehl, 1994):

$\rho_{/}(z)=0.21 e^{\left(-\frac{z}{h_{l}}\right)}$

$h_{\text {/ }}$ is a time-independent, meridionally varying, empirically derived characteristic cloudwater scale height, evaluated using

$h_{l}=A+B \cos ^{2} \phi_{i}$

20 where $A=1080 \mathrm{~m}$ and $B=2000 \mathrm{~m}$. In-cloud liquid water path, LWP, is than evaluated using this vertically distributed cloud condensate as

$\mathrm{LWP}=\rho_{/}(z) d z$

Aerosol-cloud interactions in the NASA GMI

N. Meskhidze et al.

Title Page

Abstract

Introduction

Conclusions

References

Tables

Figures

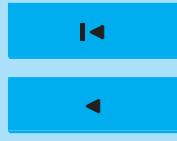

$\rightarrow$

Back

Close

Full Screen / Esc

Printer-friendly Version

Interactive Discussion 


\subsubsection{Aerosol-cloud interactions}

Empirical and prognostic approaches for representing the aerosol-cloud droplet number concentration (CDNC) link are implemented in GMI. Empirical approaches bypass the physics of linking aerosol with clouds by correlating CDNC with an aerosol proxy 5 such as mass or aerosol number concentration (e.g., Boucher and Lohmann, 1995; Gultepe and Isaac, 1996; Segal and Khain, 2006). The major disadvantage of this approach is that they are based on phenomenological correlations from observations (or simulations) of limited spatiotemporal coverage, and as such, are inherently subject to significant uncertainty resulting from unresolved variations in the aerosol size distribution, chemical composition and atmospheric dynamics (i.e., cloud updraft velocity fields) (Leaitch et al., 1996; Feingold et al., 1999; Menon et al., 2002; Lance et al., 2004). Nevertheless, empirical correlations are still used in GCM studies because they are simple to implement and computationally inexpensive.

In this study, the empirical correlations of Boucher and Lohmann (1995) (referred to 15 as BL hereafter) is employed that estimates the CDNC from the mass concentration of sulfate:

$N_{d}= \begin{cases}10^{2.06+0.480 \log (m)} & \text { over oceans } \\ 10^{2.24+0.257 \log (m)} & \text { over land }\end{cases}$

where $N_{d}$ is the droplet number $\left(\mathrm{cm}^{-3}\right)$ and $m$ is the sulfate mass $\left(\mu \mathrm{g} \mathrm{m}^{-3}\right)$.

In the prognostic approach, CDNC is explicitly computed from a relationship (commonly referred to as "mechanistic" or "prognostic" parameterization) which expresses the physics of cloud droplet formation and growth. This study uses the work of Fountoukis and Nenes (2005) (referred as FN hereafter) that can treat the activation of multimodal lognormal aerosol. This parameterization has extensively been evaluated with detailed numerical simulations (Fountoukis and Nenes, 2005) and in-situ data for a wide range of cloud formation conditions (Meskhidze et al., 2005; Fountoukis et al., 2007). FN is based on the framework of an ascending cloud parcel with the maxi-

\section{Aerosol-cloud interactions in the NASA GMI}

N. Meskhidze et al.

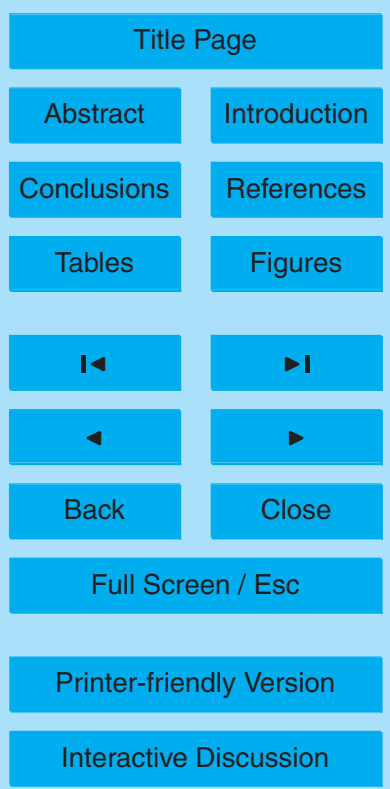


mum supersaturation, $s_{\max }$, controlling CDNC. Droplets are classified by the proximity to their critical diameter ("population splitting"), allowing $s_{\max }$ to be determined from the numerical solution of an algebraic equation. Population splitting also allows the accurate treatment of complex aerosol chemistry and kinetic limitations on droplet growth 5 (e.g., Fountoukis and Nenes, 2005).

FN parameterization requires information on aerosol composition, size distribution and cloud-scale updraft velocity. As aerosol microphysical information is not available from the GMI simulation, they are constrained by published observations (e.g., Whitby, 1978; Lance et al., 2004) of trimodal lognormal aerosol scaled to the simulated 10 aerosol mass. Aerosol over land (excluding the areas covered by land ice) is considered "continental", while over ocean (excluding the areas covered by sea ice) is treated as "marine". Sulfate concentrations from the online simulation are used to scale the size distribution of aerosols in different parts of the globe by using the same modal geometric mean diameter $\left(D_{g i}\right)$ and geometric standard deviation $\left(\sigma_{g i}\right)$ for each aerosol 15 mode $(i)$ while the mode concentration $\left(N_{i}\right)$ is multiplied by $m_{\mathrm{SO}_{4}} / \sum m_{i}$, where $m_{\mathrm{SO}_{4}}$ is the sulfate mass predicted by GMI in each cell and $\sum m_{i}$ is the total sulfate in the prescribed aerosol distribution. Marine aerosol chemical composition is assumed to be $67 \%$ insoluble and $33 \%$ ammonium sulfate in the fine mode, and $5 \%$ insoluble and $95 \%$ sea-salt in the coarse mode (Table 1, Lance et al., 2004). The continental aerosol

20 is assumed to be $50 \%$ insoluble and $50 \%$ ammonium sulfate in both coarse and fine modes.

Cloud-scale updraft velocity is not available from the GMI simulations and is prescribed. One mean value is used for "continental" and for "marine" clouds equal to $1 \mathrm{~m} \mathrm{~s}^{-1}$ and $0.35 \mathrm{~m} \mathrm{~s}^{-1}$ respectively. In reality, updraft velocity varies significantly within 25 a stratocumulus cloud deck (Lohmann et al., 1999; Meskhidze et al., 2005), and the average concentration over the distribution of updrafts should be used. However, it was shown by Meskhidze et al. (2005) that usage of an average cloud-scale updraft velocity (i.e., the positive part of the vertical velocity spectrum) gives optimal closure for cumulus and stratocumulus clouds and therefore is appropriate for calculating cloud

\section{ACPD}

7, 14295-14330, 2007

\section{Aerosol-cloud interactions in the NASA GMI}

N. Meskhidze et al.

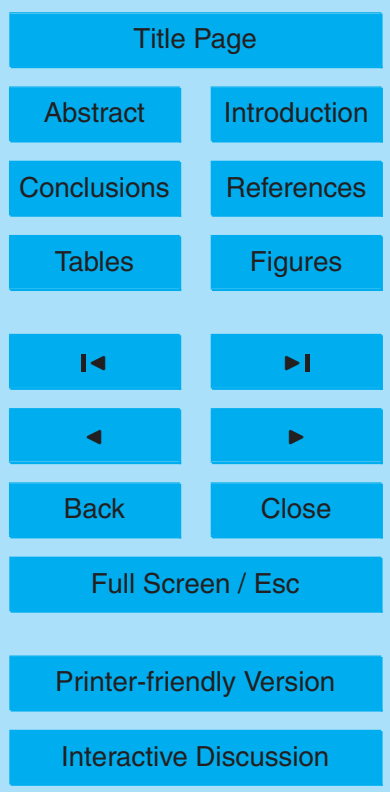


droplet number. Fountoukis et al. (2007) further showed that the average updraft velocity (also shown to yield optimum closure for clouds over the continental U.S. during the International Consortium for Atmospheric Research on Transport and Transformation Experiment, ICARTT) characterizes the probability distribution of vertical velocities in a 5 steady-state boundary layer, and, is identical to the "characteristic" velocity shown by Peng et al. (2005) which yields the probability-averaged droplet number.

\subsubsection{Cloud radiative properties}

All calculations presented here concern only purely warm clouds defined as those with cloud top temperature $273 \mathrm{~K}$ and above. The cloud optical thickness, $\tau_{c}$, is computed 10 as

$\tau_{c}=\frac{3}{2} \frac{\mathrm{LWC} h}{\rho_{w} r_{e}}$

where $\rho_{w}$ is the density of water, LWC is the liquid water content in the cloudy part of the grid box, $h$ is the cloud height and $r_{e}$ is the droplet effective radius given by

$r_{e}=\frac{3}{2}\left(\frac{\mathrm{LWC}}{4 \pi \rho_{w} k N_{d}}\right)^{\frac{1}{3}}$

15 where $N_{d}$ is the cloud droplet number concentration and $k$ is a coefficient relating the volumetric mean to effective radius $(k \sim 0.67$ for continental air masses and 0.80 for maritime air masses Martin et al., 1994). Integration of Eq. (9) and substitution into Eq. (8) gives $\tau_{c}$ as a function of $N_{d}$. The cloud optical depth (COD) is then calculated from Eq. (10) and used in the model's shortwave (SW) radiation calculations as shown 20 in Sect. 2.3.

To account for the vertical subgrid variability of clouds, an approximation to the random overlap (RAN) assumption is used (Briegleb, 1992):

$\tau=\tau_{C} C^{\frac{3}{2}}$

\section{Aerosol-cloud interactions in the NASA GMI}

N. Meskhidze et al.

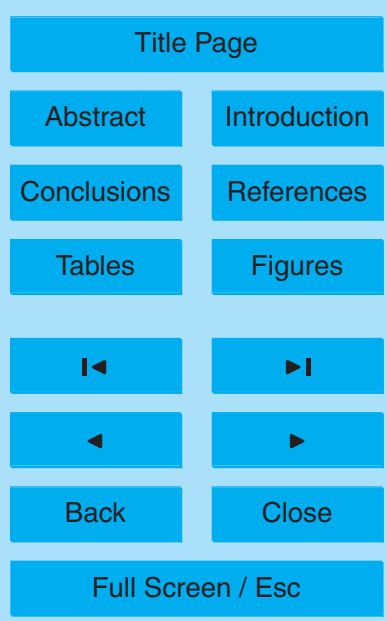

Printer-friendly Version

Interactive Discussion 
where $\tau_{c}$ is the cloud optical thickness in the cloudy portion of the grid Eq. (8). Briegleb (1992) showed that this formulation, although computationally much simpler than explicit random overlap calculation, is a reasonable approximation when computing IR radiative heating rates. Feng et al. (2004) also demonstrated that Eq. (10) is a good 5 approximation of random overlap when computing photolysis rates for large cloud fractions (above $50 \%$ ). For small cloud fraction (around $20 \%$ ) and high liquid water content, there are relatively large errors (40-50\%).

\subsection{Computation of indirect forcing}

A radiative transfer code is currently not available in GMI. For this, the existing Fast$10 \mathrm{~J}$ algorithm (Wild, 2000) has been modified to calculate changes in shortwave fluxes from the presence of clouds online. Changes in the longwave (LW) radiation are not considered. In doing so, the visible and ultraviolet sunlight with wavelengths from 180 to $800 \mathrm{~nm}$ (used in Fast-J) has been extended to $4000 \mathrm{~nm}$ to include the entire solar spectrum (using the reference published spectra of a Simple Model of the Atmospheric 15 Radiative Transfer of Sunshine, SMARTS2, Gueymard et al., 1995). The number of wavelength bins in the expanded scheme has been increased from 18 to 30; the cross sections for species of interest have been weighted by the solar flux and then lumped into the appropriate bin. In the near infrared part of the spectrum, the water vapor absorption has also been added.

Solar radiation transmitted through each vertical layer, I, is calculated as

$I_{l}=I_{I}^{\text {att }}\left(1-\alpha_{l}\right)$

where $I_{I}^{\text {att }}$ is the incident beam for given solar zenith angle attenuated in layer "I" due to atmospheric gases, and $1-\alpha_{l}$ is the transmittance through the cloudy grid cell. $\alpha_{I}$ is the cloud albedo calculated using a two-stream approximation of a non-absorbing,

\section{Aerosol-cloud interactions in the NASA GMI}

N. Meskhidze et al.

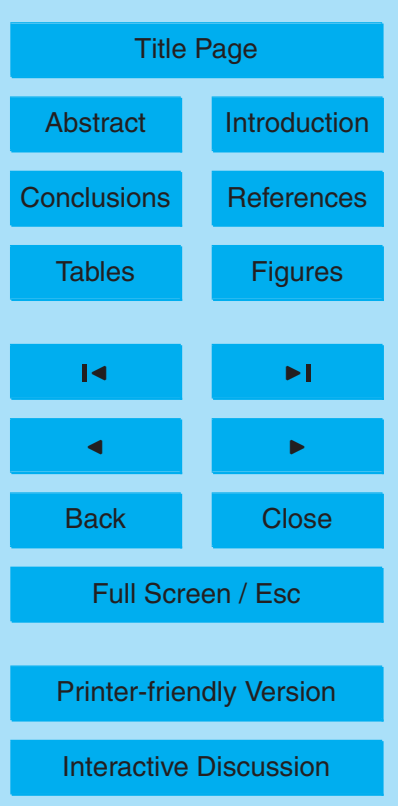


where $\tau$ is the COD, accounting for the effect of random overlap Eq. (10), in each gridpoint and timestep.

5 Aerosol indirect forcing (IF) is computed as the difference in the net whole-sky shortwave incoming flux at the surface between simulations that use present-day (PD; natural plus anthropogenic) and pre-industrial (PI; natural only) emissions.

As shown in Table 2, IF computed with the modified FAST-J is higher than expected $\left(\sim 2 \mathrm{~W} \mathrm{~m}^{-2}\right)$, and is attributed to the simplistic treatment of clouds and lack of other 10 components that affect radiation (e.g., aerosol direct effects). Nevertheless, the forcing, even if overestimated, scales as expected with changes in aerosol loading and CDNC for all meteorological fields considered (not shown). This means that relative changes in IF are captured by the modified FAST-J algorithm, and IF can be appropriately "scaled-down", provided that it is known for a given global distribution of sulfate 15 and cloud fields. This is possible using the NASA GISS II' meteorological fields, as Sotiropoulou et al. (2007) computed IF online in the same GCM using a similar online sulfate aerosol simulation. The similarity between both simulation frameworks is striking; Table 2 shows present-day and pre-industrial values of CDNC (computed using the FN parameterization), COD (outputs on a monthly basis), and \% changes thereof for both GMI and online GISS II' GCM simulations. The agreement in predictions of CDNC and COD (hence the resulting IF) between the two frameworks is remarkable; one can assume then that the simplified FAST-J algorithm in GMI overestimates IF by a factor of two. Therefore, the scaling factor, $F$ (calculated as the ratio of the indirect forcings between GISS II' GCM, IF $\mathrm{GISSII}$, and GMI, IF $\mathrm{GMI}$, Fig. 1), is 0.5 , and applied to all simulations presented hereon.

\section{Aerosol-cloud interactions in the NASA GMI}

N. Meskhidze et al.

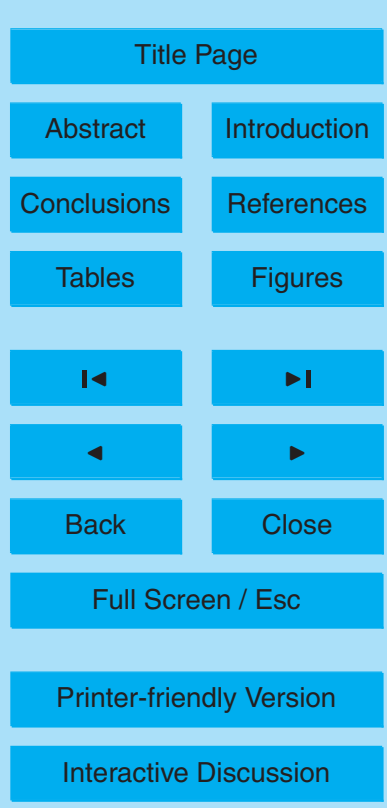




\section{Results and discussion}

\subsection{Sulfate burden}

Figure 2 presents the annual mean sulfate concentrations for the surface layer using present day emissions and the three meteorological fields (DAO, FVGCM, GISS). As 5 expected, higher sulfate concentrations are predicted over the industrialized regions in the mid-latitudes of the Northern Hemisphere for all three meteorological fields. On a global scale, FVGCM predicts 1.4 and 1.3 times higher concentrations than DAO and GISS, respectively, while it presents the strongest long-range transport of pollution plumes; GISS fields have the weakest long range transport. As a result, over the oceanic regions the differences in the predictions of sulfate concentrations between the three meteorological fields are quite large, with FVGCM predicting $\sim 2$ and $\sim 1.5$ times (on average) higher values than DAO and GISS respectively. The stronger poleward transport of sulfate in the DAO fields result in a factor of 2-3 higher sulfate concentrations, compared to FVGCM and GISS fields.

15 The global sulfate burden is $0.8,0.6$ and $0.7 \mathrm{Tg} \mathrm{S} \mathrm{yr}^{-1}$ for DAO, FVGCM and GISS respectively. These burdens lie well within other values reported in the literature (e.g., Chin and Jacob, 1996; Feichter et al., 1996; Lohmann and Feichter, 1997; Chuang and Walton, 1997; Roelofs et al., 1998; Koch et al., 1999; Rasch et al., 2000; Rotstayn and Lohmann, 2002). A more detailed description can be found in Liu et al. (2007).

\subsection{Cloud droplet number concentration}

Figure 3 presents global distributions of simulated yearly averaged CDNC for the lowest cloud-forming level; CDNC is shown for all meteorological fields and cloud droplet parameterizations, assuming current-day emissions. The distribution of CDNC in all model simulations exhibit the same spatial pattern: the highest CDNC is found near heavily polluted areas of the Northern Hemisphere (NH) (i.e., over China, Western Europe, eastern coast of the U.S. and the Gulf of Mexico), consistent with the high level

\section{Aerosol-cloud interactions in the NASA GMI}

N. Meskhidze et al.

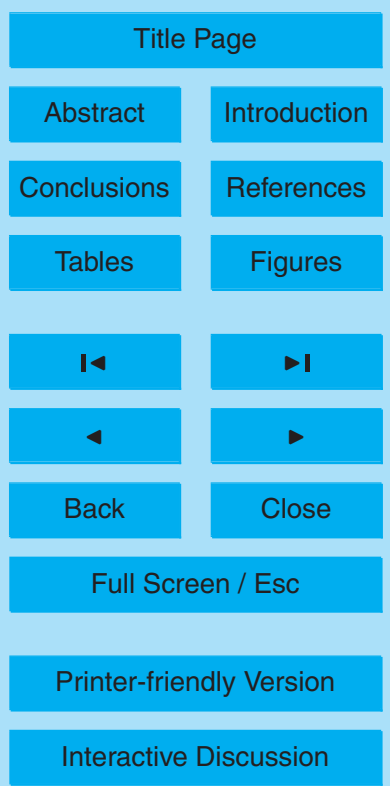


of aerosol associated with industrialized regions. As expected, CDNC over the remote oceans and in the polar regions are lower. The effects of trade winds off the subtropical west coasts of Africa and America, and westerlies in midlatitude east coasts of North America and Asia are clearly depicted in Fig. 3. In these regions CDNC increase, as 5 clouds are influenced by long-range transport of continental air masses into adjacent ocean areas (c.f. Prospero et al., 1983; Minnis et al., 1992). In contrast to the $\mathrm{NH}$, smaller droplet number is found over the oceans of the Southern Hemisphere (SH) as a result of the cleaner air masses characterizing these regions. Over the Southern Ocean larger CDNC are predicted over biologically active regions due to the enhanced 10 production of sulfate from dimethyl sulfide (DMS) oxidation. Over the continents of the $\mathrm{SH}$, larger CDNC appears over region affected by biomass burning such as South America and West Africa. As expected, CDNC decreases with altitude (not shown).

Despite their qualitative agreement, the global average and geographic distribution of CDNC reveal considerable differences when meteorological fields and droplet parameterizations are changed (Fig. 3). For all three meteorological fields, CDNC using the $\mathrm{BL}$ correlation is higher compared to using FN parameterization (Fig. 3). The difference in CDNC between the two cloud schemes is consistent under DAO and GISS meteorological fields. For FVGCM, the difference is quite larger; this is caused by the higher sulfate loading in the industrialized regions that leads to large discrepancies between the cloud schemes. CDNC is highest for simulations using FVGCM fields and lowest for DAO (Fig. 3), as differences in long-range transport strongly impact aerosol (sulfate) concentration (Fig. 2). Over the heavily polluted industrial areas of the $\mathrm{NH}$, FN parameterization results in about 70 to $1000 \%$ higher CDNC (e.g., China). The two schemes also differ in their predicted droplet number over the oceans where BL scheme predicts 10 to $80 \%$ higher CDNC values compared to $\mathrm{FN}$ scheme. Even if biases between the meteorological fields and parameterizations tend to cancel out in the global averages, local effects can be large, with important implications for climate response to the forcing.

Modeled CDNC near the surface appear to correspond reasonably well with remote

\section{Aerosol-cloud interactions in the NASA GMI}

N. Meskhidze et al.

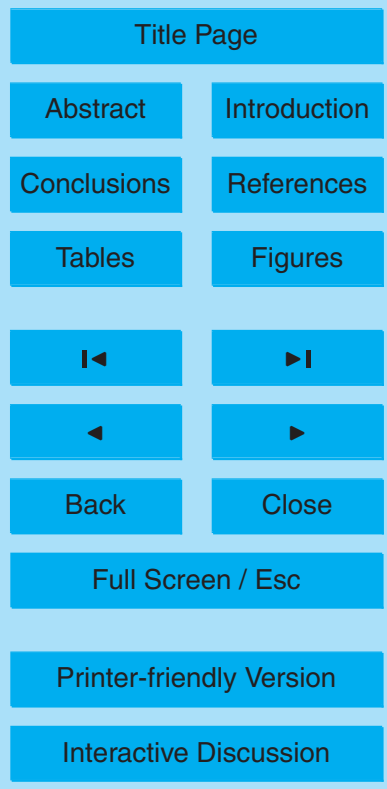


sensing retrievals (Meskhidze and Nenes, 2006), in-situ data (e.g., Menon et al., 2003; Snider et al., 2003; Conant et al., 2004; Meskhidze et al., 2005; Fountoukis et al., 2007) and other modeling studies (e.g., Kristjánsson, 2002; Sotiropoulou et al., 2007) (Table 3).

\section{Model evaluation with satellite observations}

Predicted cloud droplet effective radius, column number concentration and COD is evaluated with satellite retrievals from the Moderate Resolution Imaging Spectroradiometer (MODIS) platform. In this study, we use MODIS Terra Collection 005 (C5) Level-3 global gridded products averaged at $1^{\circ}$ by $1^{\circ}$ resolution. The $\mathrm{C} 5$ data products 10 are produced using the latest available versions of the science algorithms developed by the MODIS Land Science Team (King et al., 2006); Quality assured (QA) pixelweighted cloud properties are used. To minimize the inter-annual variation in MODIS retrievals, for each parameter composites were made using monthly averaged data for seven (2000-2006) years of MODIS available data.

15 To compare the MODIS retrieved cloud properties (i.e., effective radius and optical thickness) with the model predictions, the cloud top height was determined by finding the highest level with liquid water content larger than $10^{-9} \mathrm{~g} \mathrm{~m}^{-3}$ and cloud temperature higher than $273 \mathrm{~K}$.

\subsection{Droplet Effective Radius}

It is well known that satellite-retrieved $r_{e}$ is characteristic of the cloud top (Boucher and Lohmann, 1995; Quaas et al., 2004; Chen and Penner, 2005) while model derived values are cloud-averages. To compensate for this (assuming that LWC varies linearly from cloud base and CDNC remains constant throughout the cloud), model effective radius is recalculated at $2 \times L W C$, to approximate conditions at cloud top. As can be seen in Eq. (9), doubling LWC is equivalent to multiplying the modeled effective radius

\section{ACPD}

7, 14295-14330, 2007

Aerosol-cloud interactions in the NASA GMI

N. Meskhidze et al.

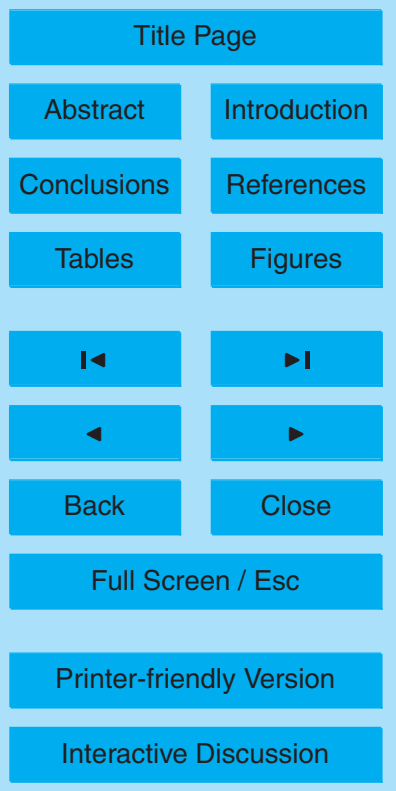

EGU 
fields with $2^{1 / 3}$.

Figure 4 presents the 7-year mean MODIS-retrieved cloud droplet effective radii along with the model predictions for the two cloud formation parameterizations and the three meteorological fields used. As illustrated by the figure, the simulated effective

5 radius captures the spatial patterns seen in the satellite data. In agreement with the MODIS remotely sensed data, the maximum droplet size is calculated over the western tropical Pacific warm pool region, as a result of the large evaporation associated with large sea surface temperature that leads to a high LWP and a small number of cloud droplets that cause the formation of large droplet sizes. The smallest effective radius 10 is calculated over continental regions with enhanced CCN concentration (i.e., eastern China, North America and Western Europe), and reflects the aerosol indirect effect over these regions.

Although the spatial patterns of the effective radii using different cloud droplet parameterizations are similar, there are important quantitative differences. For all me15 teorological fields, the effective radius calculated using FN is higher compared to the one predicted using $\mathrm{BL}$; this difference is most pronounced over the oceans (Fig. 4) where FN predicts $10-30 \%$ higher values compared to BL scheme. These differences can result from variations in LWC and CDNC Eq. (9); since the LWC in each meteorological field is the same, regardless of droplet parameterization, changes in $r_{e}$ only result from differences in predicted CDNC. As expected, $r_{e}$ predictions mostly differ over highly susceptible marine clouds (e.g., Platnick and Twomey, 1994; Taylor and McHaffie, 1994), especially for simulations using the DAO meteorological field (which tend to have largest LWC of all meteorological fields).

Table 4 summarizes effective radius values for all meteorological fields and droplet parameterizations used in the present study. Satellite and model values agree reasonably well in terms of the land-ocean contrast and the differences between the $\mathrm{SH}$ and the $\mathrm{NH}$ regions. The mean cloud droplet radii over the $\mathrm{NH}$ are smaller than in the SH with the maritime difference $(\sim 1.3 \mu \mathrm{m})$ somewhat smaller than the continental one $(\sim 1.8 \mu \mathrm{m})$. The particle radii over the continents are systematically smaller

\section{Aerosol-cloud interactions in the NASA GMI}

N. Meskhidze et al.

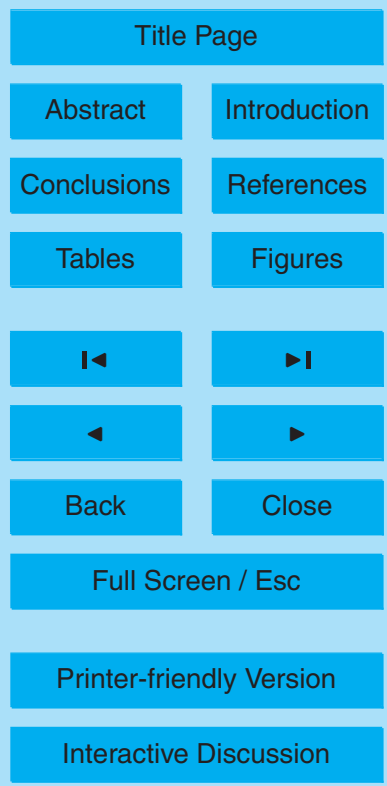

EGU 
compared to those over the oceans, as revealed by previous satellite retrievals (e.g., Han et al., 1994; Kawamoto et al., 2001; Suzuki et al., 2004; Jin and King, 2007 ${ }^{1}$ ). Average land/ocean ratio of $\sim 0.77$ (Table 4 ) in model simulated effective radius also compares well with $\sim 0.72$ and 0.80 ratios observed by the International Satellite Cloud 5 Climatology Project (ISCCP) (Han et al., 1994) and MODIS respectively.

Despite the qualitative agreement between satellite retrievals and model predictions, in all simulations the effective radius is underpredicted by the model (Table 4). The simulated global mean effective radius over the land and the ocean are systematically lower compared to MODIS retrieved values. Such biases are common in many present 10 GCMs (e.g., Boucher and Lohmann, 1995; Quaas et al., 2004; Chen and Penner, 2005) pointing to the uncertainties associated with the retrieval algorithms, the fixed size distribution used, the poor representations of the updraft velocity, uncertainties in LWC and its variability, the model resolution used and the poor cloud parameterizations.

\subsection{Cloud optical thickness}

15 Figure 5 presents the 2000-2006 average geographical distributions of the retrieved liquid COD from MODIS platform and the annual average COD calculated by GMI. Similar general patterns of COD are predicted for meteorological fields and droplet formation parameterizations, comparable with those retrieved from MODIS. The simulations capture the differences between the land and the ocean. The model predicts higher optical thickness for the clouds over anthropogenically influenced regions of eastern China, Europe, eastern U.S., and some biomass burning regions in South America and West Africa.

Despite the qualitative agreement in the geographical distribution of model predicted and MODIS observed COD, Table 5 shows that simulated global mean COD is lower than the one derived from the satellite data. The differences are more pronounced over

\footnotetext{
${ }^{1} \mathrm{Jin}$, M. and King, M. D.: Observed land-sea contrasts on clouds, water vapor, and rainfall at continental scales, J. Climate, in review, 2007.
}

\section{Aerosol-cloud interactions in the NASA GMI}

N. Meskhidze et al.

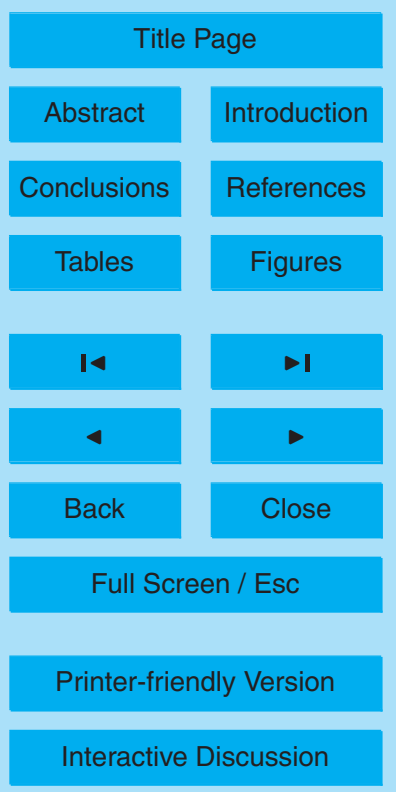


the continents, and particularly over the SH land. MODIS retrieved values of COD are systematically higher compared to that of ISCCP.

\section{Short-wave indirect aerosol forcing}

Figure 6 presents global distributions of simulated annual mean first aerosol indirect 5 forcing for all meteorological fields and droplet parameterizations. The globally averaged AIE is found to range between -0.99 and $-1.48 \mathrm{Wm}^{-2}$ (Fig. 6). Maximum value of AIE is reached for FVGCM meteorological dataset with FN droplet activation scheme, while the minimum value was predicted for GISS II' meteorological fields with $\mathrm{BL}$ droplet scheme. Different meteorological datasets are predicted to contribute $82 \%$ variability in globally averaged AIE, while results from different cloud droplet parameterizations contribute a variability of $18 \%$.

AIE spatial variation is substantial, with the largest values predicted over SE Asia, Western Europe and Eastern U.S. (i.e., areas with highest amount of anthropogenic sulfur emissions). Figure 6 also reveals small but non-trivial values of AIE near industrialized centers and biomass burning regions in the $\mathrm{SH}$ following the spatial patterns of CDNC. All meteorological fields and cloud droplet schemes predict (Fig. 6, Table 6) larger AIE over the continents than over the oceans. Long range transport of the pollution plumes leads to an anthropogenic influence far into oceanic regions (Fig. 6).

Despite the qualitative similarity in the spatial patterns for all the globally average 20 indirect forcing, predictions by FN parameterization tend to be higher than using the BL scheme (Fig. 6). Over the continents, FN predicts higher values of indirect forcing (droplet concentrations) compared to $\mathrm{BL}$; this is more pronounced over the polluted industrial regions of the $\mathrm{NH}$ (i.e., over China, Western Europe, eastern coast of the U.S. and the Gulf of Mexico) where FN results in about 30 to $50 \%$ higher indirect forcing. Over the SH oceans, central Atlantic ocean and Amazon, FN predicts lower indirect forcing values compared to $\mathrm{BL}$ scheme.

\section{Aerosol-cloud interactions in the NASA GMI}

N. Meskhidze et al.

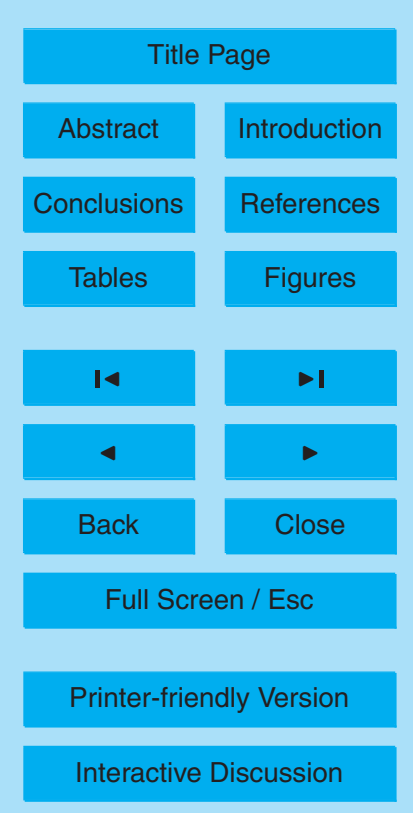




\section{Conclusions and implications}

The NASA Global Modeling Initiative (GMI) 3-D chemistry-transport model (CTM) has been extended to include the impacts of aerosol on SW cloud albedo, for the purpose of assessing the impact of droplet parameterizations and meteorological fields from 5 different GCMs on indirect forcing. Simulations were carried out for "present day" and "preindustrial" emissions using three different meteorological datasets, the NASA Data Assimilation Office (DAO), the NASA finite volume GCM (FVGCM) and the Goddard Institute for Space Studies version II' (GISS II') GCM and two cloud droplet parameterizations, the empirical scheme of Boucher and Lohmann (1995) and the prognostic of

10 Fountoukis and Nenes (2005). The aerosol size distribution was obtained by scaling prescribed distributions to aerosol mass simulated online; in-cloud updraft velocity required for calculating droplet number with FN is prescribed. To calculate the first AIE, the Fast-J (Wild, 2000) algorithm was extended for the whole solar spectrum to computed changes in incoming shortwave radiation, scaled to match online SW radiative 15 forcing obtained with the GISS GCM II'.

In all simulations, larger values of CDNC are predicted in regions in the vicinity of pollution (China, North America, and Europe) and long range transport thereof (North Atlantic). Different droplet schemes may account for $15 \%$ variability in calculation of global annual mean CDNC, leaving the key role to the meteorological fields used.

The calculated annual mean indirect forcing ranges from -0.99 to $-1.48 \mathrm{~W} \mathrm{~m}^{-2}$. The smallest value is predicted for the BL droplet scheme with GISS II' meteorological fields, while the largest value is obtained with the FN scheme using FVGCM fields. Our results suggest that for the same droplet parameterizations, different meteorological fields can cause up to $82 \%$ variation in predicted AIE. In addition to the variation in the calculated global average, significant discrepancies can also be observed in the spatial distribution of AIE. FVGCM and DAO meteorological fields are typically more dispersive and allow pollutants to be transported over the oceans far away from the source regions. In such regions, clouds are potentially more sensitive to an increase in

\section{ACPD}

7, 14295-14330, 2007

\section{Aerosol-cloud interactions in the NASA GMI}

N. Meskhidze et al.

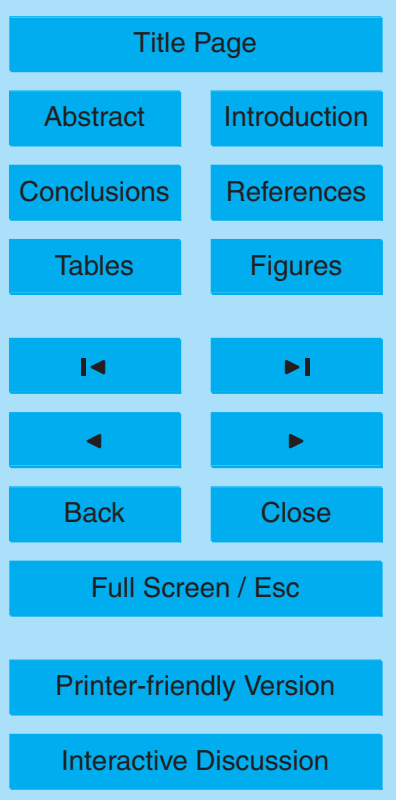


CCN (Platnick and Twomey, 1994; Taylor and McHaffie, 1994) due to clouds susceptibility or the change in albedo relative to the change in droplet number concentration. Differences in the spatial patterns of indirect forcing are also predicted using different droplet schemes. The AIE predicted by the FN scheme was typically lower over the 5 polluted regions and over the oceans downwind of pollution sources compared to the $\mathrm{BL}$ scheme.

The derived cloud properties, such as COD and effective radius were compared with the remotely sensed data from MODIS platform. Analysis of the results show that the model is able to capture the retrieved land-ocean contrast and the patterns 10 of the spatial distributions observed in remotely sensed data. However, the simulated global mean values of both the effective radius and the COD are systematically lower than those observed from MODIS satellites. Underestimation of these properties is common in many present GCMs and can be associated with the uncertainties in the retrieval of cloud properties from satellite data and also to uncertainties associated with the GCMs, e.g., the fixed size distribution used, the poor representations of the updraft velocity, uncertainties in LWC and its variability, the model resolution and the poor cloud parameterizations.

This study suggests that uncertainties associated with variability in liquid water path and long range transport of sulfate dominate against the formulation used for describing the aerosol-cloud drop link, at least for the cloud schemes used in this study. However, aerosol microphysics in this version of the GMI code is mass-based; using a fixed size distribution which produces droplet numbers that are consistent with BL (Lance et al., 2004) still results in a $20 \%$ variability from the aerosol-droplet parameterization. This suggests that $20 \%$ is the lower limit in variability expected for the aerosol-cloud droplet interactions parameterization. Explicit microphysics with a more diverse chemical composition are expected to introduce larger uncertainty in the impact from the aerosol-drop link relationship and is the subject of future study.

Acknowledgements. We would like to acknowledge the support from National Aeronautics and Space Administration (NASA) New Investigator Award, a NASA EOS-IDS, an NSF CAREER

\section{Aerosol-cloud interactions in the NASA GMI}

N. Meskhidze et al.

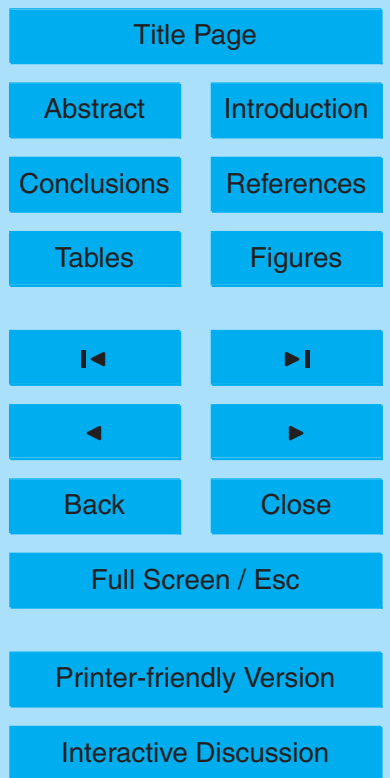

EGU 


\section{References}

Boucher, O. and Lohmann, U.: The sulfate-CCN-cloud albedo effect - A sensitivity study with 2 general circulation models, Tellus B, 47, 281-300, 1995. 14300, 14307, 14309, 14311, 14327, 14328, 14329, 14330

Briegleb, B. P.: Delta-Eddington approximation for solar radiation in the NCAR community climate model, J. Geophys. Res., 97, 7603-7612, 1992. 14302, 14303

Chen, Y. and Penner, J. E.: Uncertainty analysis for estimates of the first indirect effect, Atmos. Chem. Phys., 5, 2935-2948, 2005, http://www.atmos-chem-phys.net/5/2935/2005/. 14297,

Chin, M. and Jacob, D. J.: Anthropogenic and natural contributions to tropospheric sulfate: A global model analysis, J. Geophys. Res., 101, 18691-18700, 1996. 14305

Chuang, C. C., Penner, J. E., Prospero, J. M., Grant, K. E., Rau, G. H., and Kawamoto, K.: Cloud susceptibility and the first aerosol indirect forcing: Sensitivity to black carbon and aerosol concentrations, J. Geophys. Res., 107, doi:10.1029/2000JD000 215, 2002. 14297

Chuang, C. C., Penner, J. E., Taylor, K. E., Grossman, A. S., and Walton, J. J.: An assessment of the radiative effects of anthropogenic sulfate, J. Geophys. Res., 102, 3761-3778, 1997. 14305

Conant, W. C., VanReken, T. M., Rissman, T. A., Varutbangku, V., Jonsson, H. H., Nenes, A., Jimenez, J. L., Delia, A. E., Bahreini, R., Roberts, G. C., Flagan, R. C., and Seinfeld, J. H.: Aerosol-cloud drop concentration closure in warm clouds, J. Geophys. Res., 109, D13204, doi:10.1029/2003JD004 324, 2004. 14307, 14321

Considine, D. B., D.J., B., and H., L.: Sensitivity of Global Modeling Initiative chemistry and transport model simulations of radon-222 and lead-210 to input meteorological data, Atmos. Chem. Phys., 5, 3389-3406, 2005, http://www.atmos-chem-phys.net/5/3389/2005/. 14298

Feichter, J., Kjellstrom, E., Rodhe, H., Dentener, F., Lelieveld, J., and Roelofs, G.: Simulation of the tropospheric sulfur cycle in a global climate model, Atmos. Environ., 30, 1693-1707, 1996. 14305

Feingold, G., Cotton, W., Kreidenweis, S., and Davis, J.: The impact of giant cloud condensa-

\section{Aerosol-cloud interactions in the NASA GMI}

N. Meskhidze et al.

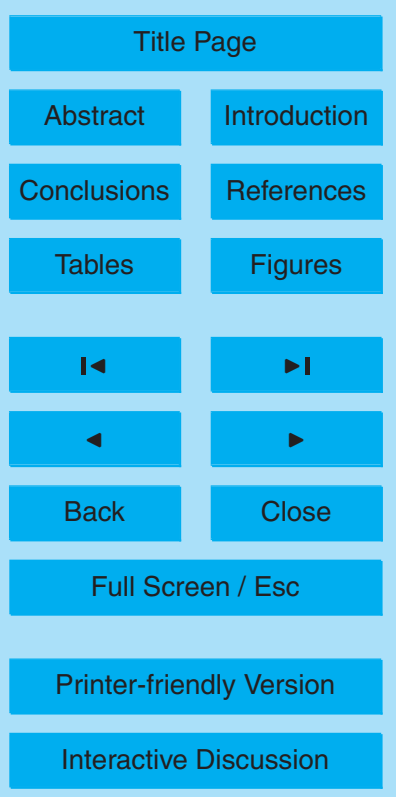


tion nuclei on drizzle formation in stratocumulus: Implications for cloud radiative properties, J. Aerosol Sci., 56, 4100-4117, 1999. 14300

Feng, Y., Penner, J. E., Sillman, S., and Liu, X.: Effects of cloud overlap in photochemical models, J. Geophys. Res., 109, D04 310, doi:10.1029/2003JD004 040, 2004. 14299, 14303

5 Fountoukis, C. and Nenes, A.: Continued development of a cloud droplet formation parameterization for global climate models, J. Geophys. Res., 110(D11212), doi:10.1029/2004JD005 591, 2005. 14300, 14301, 14311, 14320, 14327, 14328, 14329, 14330

Fountoukis, C., Nenes, A., Meskhidze, N., Bahreini, R., Buzorius, G., Conant, W. C., Jonsson, H., Murphy, S., Sorooshian, A., Varutbangkul, V., Flagan, R. C., and Seinfeld, J. H.: Aerosol cloud drop concentration closure for clouds sampled during ICARTT, J. Geophys. Res., 112, 2007. 14300, 14302, 14307, 14321

Ghan, S., Easter, R., Chapman, E., Abdul-Razzak, H., Zhang, Y., Leung, L., Laulainen, N., Saylor, R., and Zaveri, R.: A physically based estimate of radiative forcing by anthropogenic 15 sulfate aerosol, J. Geophys. Res., 106, 5279-5293, 2001. 14297

Gueymard, C., P., J., and Estradacajigal, V.: A critical-look at recent interpretations of the Angstrom approach and its future in global solar-radiation prediction, Solar Energy, 54, 357363, 1995. 14303

Gultepe, I. and Isaac, G.: The relationship between cloud droplet and aerosol number concentrations for climate models, Int. J. Climatol., 16, 941-946, 1996. 14300

Hack, J. J.: Sensitivity of the simulated climate to a diagnostic formulation for cloud liquid water, J. Climate, 11, 1497-1515, 1998. 14299

Han, Q., Rossow, W., and Lacis, A.: Near-global survey of effective droplet radii in liquid water clouds using ISCCP data, J. Climate, 7(4), 465-497, 1994. 14309, 14322

Intergovernmental Panel on Climate Change (IPCC): Climate Change (2001): The Scientific Basis, Cambridge University Press, UK, 2001. 14296

Intergovernmental Panel on Climate Change (IPCC): Climate Change (2007): The Scientific Basis, Cambridge University Press, UK, 2007. 14296, 14297

Jones, A., Roberts, D. L., Woodage, M. J., and Johnson, C. E.: Indirect sulphate aerosol forcing 30 in a climate model with an interactive sulphur cycle, J. Geophys. Res., 106(D17), $20293-$ 20310, doi:10.1029/2000JD000 089, 2001. 14297

Kawamoto, K., Nakajima, T., and Nakajima, T.: A global determination of cloud microphysics with AVHRR remote sensing, J. Climate, 14, 2054-2068, 2001. 14309

\section{Aerosol-cloud interactions in the NASA GMI}

N. Meskhidze et al.

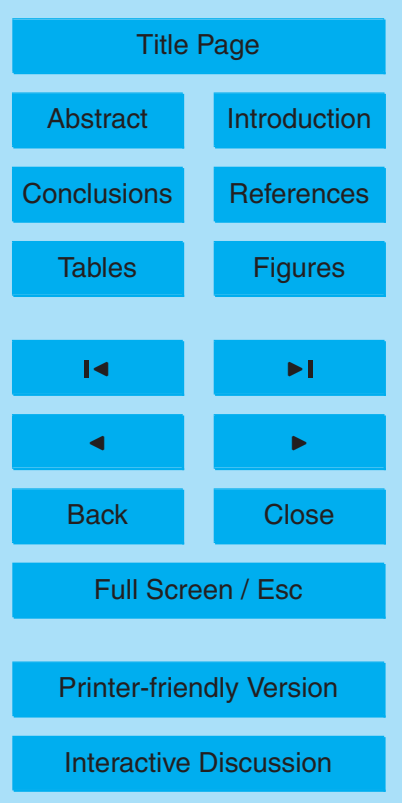


Kiehl, J. T.: Sensitivity of a GCM Climate Simulation to Differences in Continental Versus Maritime Cloud Drop Size, J. Geophys. Res., 99, 23 107-23115, 1994. 14299

Kiehl, J. T., Schneider, T. L., Rasch, P. J., Barth, M. C., and Wong, J.: Radiative forcing due to sulfate aerosols from simulations with the National Center for Atmospheric Research Com-

5 munity Climate Model, Version 3, J. Geophys. Res., 105, 1441-1457, 2000. 14297

King, M., Platnick, S., Hubanks, P. A., Arnold, G. T., Moody, E. G., Wind, G., and Wind, B.: Collection 005 change summary for the MODIS cloud optical property (06-OD) algorithm, http://modis-atmos.gsfc.nasa.gov, 101(D12), 2006. 14307

Koch, D. and Rind, D.: 10Be/7Be as a tracer of stratospheric transport, J. Geophys. Res., 103, 3907-3917, 1998. 14298

Koch, D., Jacob, D., Tegen, I., Rind, D., and Chin, M.: Tropospheric sulfur simulation and sulfate direct radiative forcing in the Goddard Institute for Space Studies general circulation model, J. Geophys. Res., 104(D19), 23 799-23 822, 1999. 14305

Kristjánsson, J. E.: Studies of the aerosol indirect effect from sulfate and black carbon aerosols, J. Geophys. Res., 107, doi:10.1029/2001JD000 887, 2002. 14297, 14307, 14321

Lacis, A. A. and Hansen, J. E.: A parameterization for the absorption of solar radiation in the earth's atmosphere, J. Aerosol Sci., 31, 118-133, 1974. 14303

Lance, S., Nenes, A., and Rissman, T. A.: Chemical and dynamical effects on cloud droplet number: Implications for estimates of the aerosol indirect effect, J. Geophys. Res., 109,D22208, doi:10.1029/2004JD004 596, 2004. 14300, 14301, 14312, 14319

Leaitch, W. R., Banic, C. M., Isaac, G. A., Couture, M. D., Liu, P. S. K., Gultepe, I., Li, S.M., Kleinman, L., Daum, P. H., and MacPherson, J. I.: Physical and chemical observations in marine stratus during the 1993 North Atlantic Regional Experiment: Factors controlling cloud droplet number concentrations, J. Geophys. Res., 101, 29 123-29 136, 1996. 14300

Liu, X., Penner, J. E., and Herzog, M.: Global simulation of aerosol dynamics: Model description, evaluation, and interactions between sulfate and nonsulfate aerosols, J. Geophys. Res., 110(D18), D18206, doi:10.1029/2004JD005674, 2005. 14298

Liu, X., Penner, J. E., Das, B., Bergmann, D., Rodriguez, J. M., Strahan, S., Wang, M., and Feng, Y.: Uncertainties in global aerosol simulations: Assessment using three meteorological datasets, J. Geophys. Res., 112, D11 212, doi:10.1029/2006JD008 216, 2007. 14305

Lohmann, U. and Feichter, J.: Impact of sulfate aerosols on albedo and lifetime of clouds: A sensitivity study with the ECHAM4 GCM, J. Geophys. Res., 102, 13685-13700, 1997. 14305

\section{Aerosol-cloud interactions in the NASA GMI}

N. Meskhidze et al.

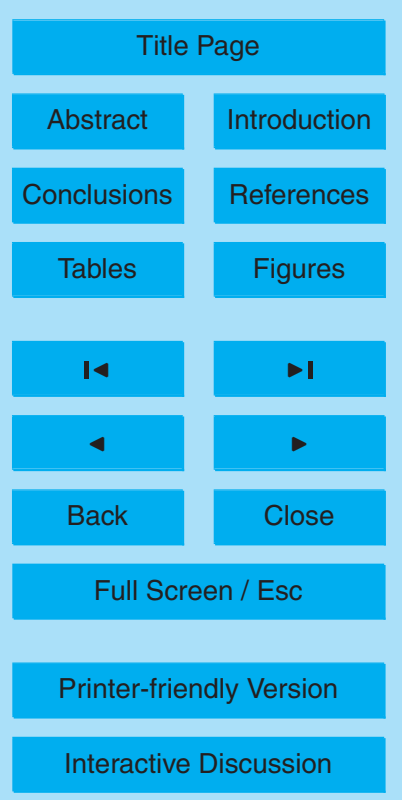


Lohmann, U. and Feichter, J.: Global indirect aerosol effects: a review, Atmos. Chem. Phys., 5, 715-737, 2005, http://www.atmos-chem-phys.net/5/715/2005/. 14297

Lohmann, U., Feichter, J., Chuang, C., and Penner, J.: Prediction of the number of cloud droplets in the ECHAM GCM, J. Geophys. Res., 104, 9169-9198, 1999. 14301

5 Lohmann, U., Feichter, J., Penner, J., and Leaitch, R.: Indirect effect of sulfate and carbonaceous aerosols: A mechanistic treatment, J. Geophys. Res., 105(D10), 12 193-12 206, 2000. 14297

Martin, G., Johnson, D., and Spice, A.: The measurement and parameterization of effective radius of droplets in warm stratocumulus clouds, J. Aerosol Sci., 51, 1823-1842, 1994.

Menon, S., DelGenio, A. D., Koch, D., and Tselioudis, G.: GCM Simulations of the aerosol indirect effect: Sensitivity to cloud parameterization and aerosol burden, J. Atmos. Sci., 59, 692-713, 2002. 14297, 14300

Menon, S., Brenguier, J.-L., Boucher, O., Davison, P., Genio, A. D., Feichter, J., Ghan, S., 15 Guibert, S., Liu, X., Lohmann, U., Pawloska, H., Penner, J., Quaas, J., Roberts, D., Schüller, L., and Snide, J.: Evaluating aerosol/cloud/radiation process parameterizations with singlecolumn models and Second Aerosol Characterization Experiment (ACE-2) cloudy column observations, J. Geophys. Res., 108(D24), 4762, doi:10.1029/2003JD003 902, 2003. 14307, 14321

20 Meskhidze, N. and Nenes, A.: Phytoplankton and Cloudiness in the Southern Ocean, Science, 314, 1419-1423, 2006. 14307, 14321

Meskhidze, N., Nenes, A., Conant, W. C., and Seinfeld, J.: Evaluation of a new cloud droplet activation parameterization with in situ data from CRYSTAL-FACE and CSTRIPE, J. Geophys. Res., 110, 2005. 14300, 14301, 14307, 14321

Minnis, P., Heck, P. W., Young, D. F., Fairall, C. W., and Snider, J. B.: Stratocumulus Cloud Properties Derived from Simultaneous Satellite and Island-Based Instrumentation During Fire, J. Appl. Meteorol., 31, 317-339, 1992. 14306

Peng, Y., Lohmann, U., and Leaitch, R.: Importance of vertical velocity variations in the cloud droplet nucleation process of marine stratus clouds, J. Geophys. Res., 110, D21213, doi:10.1029/2004JD004 922, 2005. 14302

Platnick, S. and Twomey, S.: Determining the susceptibility of cloud albedo to changes in droplet concentration with the advanced very high resolution radiometer., J. Appl. Meteor., 33, 334-347, 1994. 14308, 14312

\section{Aerosol-cloud interactions in the NASA GMI}

N. Meskhidze et al.

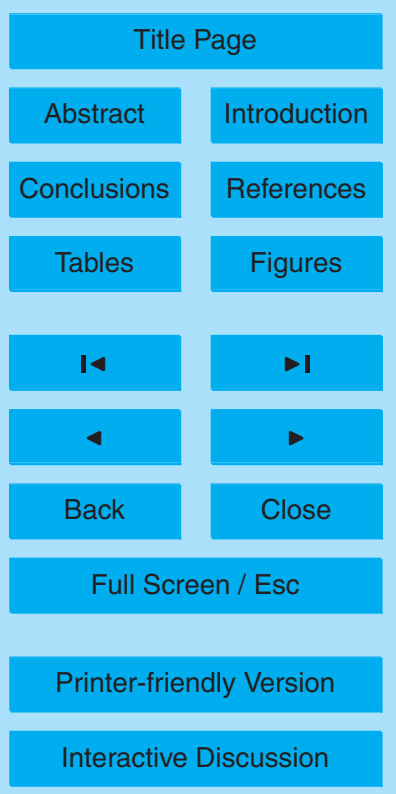


Prospero, J. M., R. J., C., Mohnen, V., Jaenicke, R., Delany, A. C., Moyers, J., Zoller, W., and Kahn, R.: The atmospheric aerosol system - An overview, Rev. Geophys., 21, 1607-1629, 1983. 14306

Quaas, J., Boucher, O., and Bréon, F.: Aerosol indirect effects in POLDER satellite data and the Laboratoire de Météorologie Dynamique-Zoom (LMDZ) general circulation model, J. Geophys. Res., 109, D08205, doi:10.1029/2003JD004 317, 2004. 14307, 14309

Rasch, P. J., Barth, M. C., Kiehl, J. T., Schwartz, S. E., and Benkovitz, C. M.: A description of the global sulfur cycle and its controlling processes in the National Center for Atmospheric Research Community Climate Model, Version 3, J. Geophys. Res., 105, 1367-1386, 2000. $10 \quad 14305$

Rind, D. and Lerner, J.: Use of on-line tracers as a diagnostic tool in general circulation model development: 1. Horizontal and vertical transport in the troposphere, J. Geophys. Res., 101, 12667-12683, 1996. 14298

Roelofs, G.-J., Lelieveld, J., and Ganzeveld, L.: Simulation of global sulfate distribution and the 15 influence on effective cloud radii with a coupled photochemistry-sulfur cycle model, Tellus, 50B, 224-242, 1998. 14305

Rotman, D., Tannahill, J., Kinnison, D., Connell, P., Bergmann, D., Proctor, D., Rodriguez, J., Lin, S., Rood, R., M.J. Prather, a. P. R., Considine, D., Ramaroson, R., and Kawa, S.: Global Modeling Initiative assessment model: Model description, integration, and testing of the transport shell, J. Geophys. Res., 106, 1669-1692, 2001. 14298

Rotstayn, L. D. and Lohmann, U.: Simulation of the tropospheric sulfur cycle in a global model with a physically based cloud scheme, J. Geophys. Res., 107, 4592, doi:10.1029/2002JD002 128, 2002. 14305

Rotstayn, L. D. and Penner, J. E.: Indirect aerosol forcing, quasi forcing, and climate response, 25 J. Climate, 14, 2960-2975, 2001. 14297

Segal, Y. and Khain, A.: Dependence of droplet concentration on aerosol conditions in different cloud types: Application to droplet concentration parameterization of aerosol conditions, J. Geophys. Res., 111, D15204, doi:10.1029/2005JD006 561, 2006. 14300

Snider, J., Guibert, S., Brenguier, J., and Putaud, J.: Aerosol activation in marine stratocumulus clouds: 2. Köhler and parcel theory closures studies, J. Geophys. Res., 108, doi:10.1029/2002JD002 692, 2003. 14307, 14321

Sotiropoulou, R. E. P., Nenes, A., Adams, P. J., and Seinfeld, J. H.: Cloud condensation nuclei prediction error from application of Köhler theory: Importance for the aerosol indirect effect,

\section{Aerosol-cloud interactions in the NASA GMI}

N. Meskhidze et al.

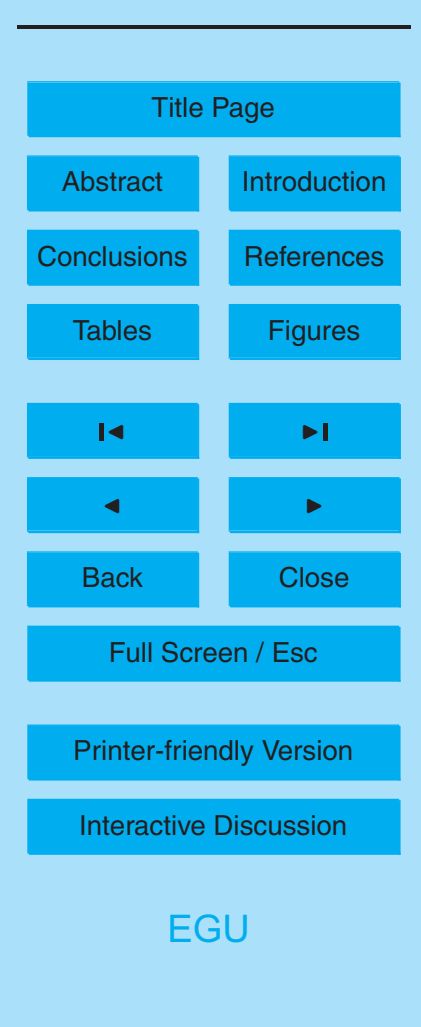


J. Geophys. Res., 34, doi:10.1029/2006JD007 834, 2007. 14304, 14307, 14320, 14321

Sundqvist, H., Berge, E., and Kristiánsson, J.: Condensation and cloud parameterization studies with a mesoscale numerical weather prediction model, Mon. Weather Rev., 117, 16411657, 1989. 14299

5 Suzuki, K., Nakajima, T., Numaguti, A., Takemura, T., Kawamoto, K., and Higurashi, A.: A study of the aerosol effect on a cloud field with simultaneous use of GCM modeling and satellite observation, J. Atmos. Sci., 61, 179-193, 2004. 14297, 14309

Taylor, J. and McHaffie, A.: Measurements of cloud susceptibility, J. Aerosol Sci., 51, 12981306, 1994. 14308, 14312

10 Whitby, K.: The physical characteristics of sulfur aerosols, Atmos. Environ., 12, 135-159, 1978. 14301

Wild, M.: Absorption of solar energy in cloudless and cloudy atmospheres over Germany and in GCMs, Geophys. Res. Lett., 27(7), 959-962, doi:10.1029/1999GL011144, 2000. 14303, 14311

$15 \mathrm{Xu}, \mathrm{K} . \mathrm{M}$. and Krueger, S. K.: Evaluation of cloudiness parameterizations using a cumulus ensemble model, Mon. Weather Rev., 119, 342-367, 1991. 14299

\section{ACPD}

7, 14295-14330, 2007

\section{Aerosol-cloud interactions in the NASA GMI}

N. Meskhidze et al.

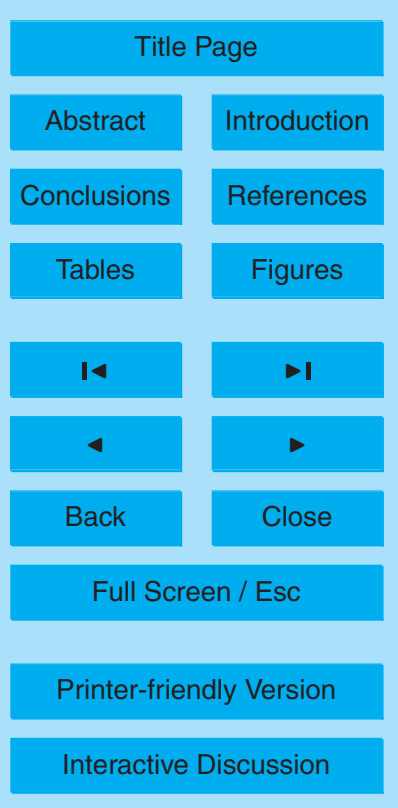

EGU 


\section{ACPD}

7, 14295-14330, 2007

\section{Aerosol-cloud interactions in the NASA GMI}

Table 1. Modal aerosol physical and chemical characteristics. Subscript " $i$ " denotes the aerosol mode, $N_{i}$ is the mode concentration $\left(\mathrm{cm}^{-3}\right), D_{g i}$ is the modal geometric mean diameter $(\mu \mathrm{m})$, $\sigma_{g i}$ is the geometric standard deviation. Characteristics obtained from Lance et al. (2004).

\begin{tabular}{ccccccc}
\hline Aerosol Mode & \multicolumn{3}{c}{ Marine aerosol } & \multicolumn{3}{c}{ Continental aerosol } \\
& Nuclei & Accumulation & Coarse & Nuclei & Accumulation & Coarse \\
\hline$N_{i}$ & 230 & 177 & 3.1 & 1000 & 800 & 0.7 \\
$D_{g i}$ & 0.02 & 0.092 & 0.58 & 0.01 & 0.067 & 0.93 \\
$\sigma_{g i}$ & 1.47 & 1.6 & 2.49 & 1.6 & 2.1 & 2.2 \\
$\varepsilon_{\text {sol }}$ & 0.33 & 0.33 & 0.95 & 0.5 & 0.5 & 0.5 \\
\hline
\end{tabular}

N. Meskhidze et al.

Title Page

Abstract

Introduction

Conclusions

References

Tables

Figures

14

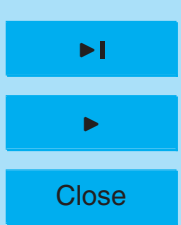

Back 


\section{ACPD}

7, 14295-14330, 2007

\section{Aerosol-cloud interactions in the NASA GMI}

Table 2. Global annual mean values of cloud droplet number concentration, $N_{d},\left(\mathrm{~cm}^{-3}\right)$ and cloud optical thickness, $\tau$, for present-day (PD) and pre-industrial (PI) emissions, absolute \% change from $\mathrm{PI}$ and annual global mean indirect forcing $\left(\mathrm{W} \mathrm{m}^{-2}\right)$ as predicted from i) GISS II' GCM with Fountoukis and Nenes (2005) parameterization and an online sulfate-based aerosol simulation, (GISS II') (Sotiropoulou et al., 2007) and ii) GMI CTM with Fountoukis and Nenes (2005) parameterization and GISS II' meteorological field, (GMI).

\begin{tabular}{lcc}
\hline Parameter & GISS II' simulation & GMI \\
\hline$N_{d},(\mathrm{PD})$ & 98.92 & 98.08 \\
$N_{d},(\mathrm{PI})$ & 41.76 & 44.66 \\
$\Delta N_{d} \%,(\mathrm{PD}-\mathrm{PI})$ & 138 & 120 \\
$\tau,(\mathrm{PD})$ & 8.76 & 8.42 \\
$\tau,(\mathrm{PI})$ & 7.97 & 7.41 \\
$\Delta \tau \%,(\mathrm{PD}-\mathrm{PI})$ & 10 & 14 \\
$\mathrm{IF}$ & 1.00 & 2.03 \\
\hline
\end{tabular}

N. Meskhidze et al.

Title Page

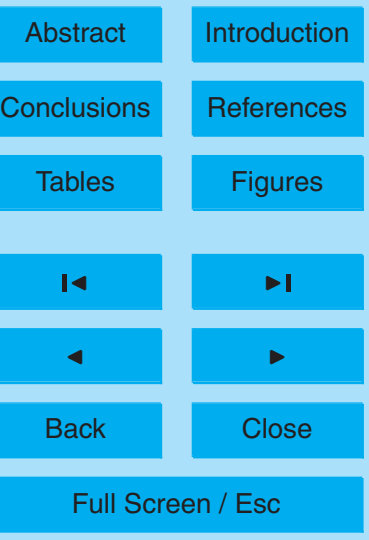

Printer-friendly Version

Interactive Discussion 


\section{ACPD}

7, 14295-14330, 2007

Table 3. Cloud droplet number concentrations $\left(\mathrm{cm}^{-3}\right)$ predicted by this study and other studies.

\begin{tabular}{|c|c|c|c|}
\hline Region & Prediction (GMI) & Cited concentration & Reference \\
\hline Clean marine & $40-160$ & $50-250$ & $\begin{array}{l}\text { Kristjánsson (2002) } \\
\text { Menon et al. (2003) } \\
\text { Snider et al. (2003) } \\
\text { Sotiropoulou et al. (2007) }\end{array}$ \\
\hline Polluted marine & 180-300 & $250-500$ & $\begin{array}{l}\text { Menon et al. (2003) } \\
\text { Snider et al. (2003) } \\
\text { Conant et al. (2004) } \\
\text { Meskhidze et al. (2005) } \\
\text { Fountoukis et al. (2007) }\end{array}$ \\
\hline Polluted Continental & $800-1300$ & $700-1500$ & $\begin{array}{l}\text { Kristjánsson (2002) } \\
\text { Meskhidze et al. (2005) } \\
\text { Fountoukis et al. (2007) } \\
\text { Sotiropoulou et al. (2007) }\end{array}$ \\
\hline Southern Ocean & 60 & 55 & Meskhidze and Nenes (2006) \\
\hline
\end{tabular}

\section{Aerosol-cloud} interactions in the NASA GMI

N. Meskhidze et al.

Title Page

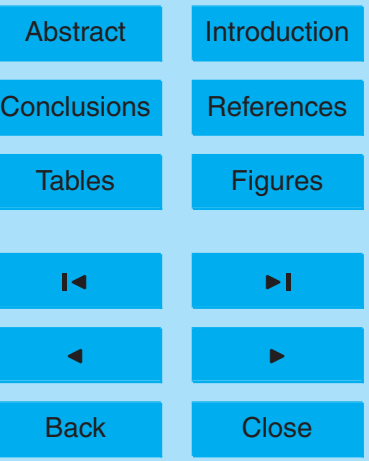

Full Screen / Esc

Printer-friendly Version

Interactive Discussion 


\section{ACPD}

Table 4. Annual average cloud mean droplet effective radii $r_{e}(\mu \mathrm{m})$ over Ocean, Land and their respective values over the Northern $(\mathrm{NH})$ and Southern $(\mathrm{SH})$ Hemispheres. Results are shown for all meteorological fields and droplet parameterizations. Retrieved values from ISCCP and MODIS platforms for the same regions are also presented. ISCCP values are obtained from Han et al. (1994). MODIS Terra Collection 005 (C5) Level-3 global gridded monthly averaged products at $1^{\circ}$ by $1^{\circ}$ resolution for April 2000-December 2006 were used. Data shown are for $70^{\circ} \mathrm{S}$ to $70^{\circ} \mathrm{N}$.

\begin{tabular}{lcccccccc}
\hline \multicolumn{1}{c}{$r_{e}$} & \multicolumn{2}{c}{ DAO } & \multicolumn{2}{c}{ FVGCM } & \multicolumn{2}{c}{ GISS } & ISCCP & MODIS \\
& $F N$ & BL & FN & BL & FN & BL & & \\
\hline Ocean & 12.24 & 11.03 & 10.98 & 9.95 & 11.80 & 10.56 & 11.80 & 15.60 \\
NH Ocean & 11.36 & 10.11 & 10.25 & 9.35 & 11.19 & 9.92 & 11.60 & 15.40 \\
SH Ocean & 12.92 & 11.72 & 11.51 & 10.38 & 12.28 & 11.03 & 12.00 & 15.80 \\
Land & 8.93 & 8.44 & 8.65 & 8.39 & 8.53 & 8.16 & 8.50 & 12.50 \\
NH Land & 8.45 & 8.19 & 8.27 & 8.18 & 8.06 & 7.87 & 8.20 & 12.40 \\
SH Land & 10.96 & 9.62 & 10.02 & 9.14 & 10.47 & 9.40 & 9.00 & 13.10 \\
\hline
\end{tabular}

\section{Aerosol-cloud} interactions in the NASA GMI

N. Meskhidze et al.

Title Page

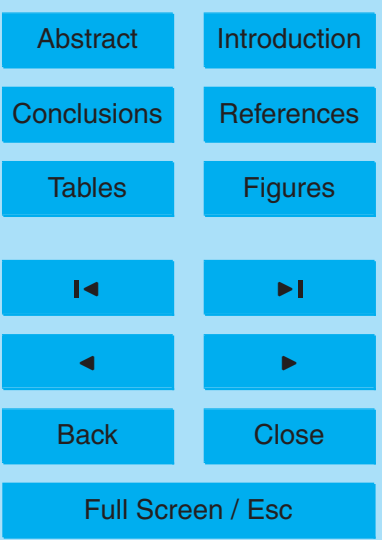

Printer-friendly Version

Interactive Discussion 


\section{ACPD}

7, 14295-14330, 2007

\section{Aerosol-cloud} interactions in the NASA GMI

N. Meskhidze et al.

Table 5. Same as Table 4, but for cloud optical depth.

\begin{tabular}{lcccccccc}
\hline \multicolumn{1}{c}{$\tau$} & \multicolumn{2}{c}{ DAO } & \multicolumn{2}{c}{ FVGCM } & \multicolumn{2}{c}{ GISS } & ISCCP & MODIS \\
& FN & BL & FN & BL & FN & BL & & \\
\hline Ocean & 8.38 & 9.19 & 11.45 & 11.76 & 9.42 & 10.26 & 6.90 & 11.20 \\
NH Ocean & 7.53 & 8.38 & 12.04 & 11.99 & 9.24 & 10.15 & 6.40 & 10.70 \\
SH Ocean & 8.89 & 9.67 & 10.95 & 11.55 & 9.38 & 10.14 & 7.40 & 11.50 \\
Land & 5.82 & 6.19 & 9.57 & 7.93 & 10.74 & 11.15 & 8.10 & 15.70 \\
NH Land & 5.87 & 6.13 & 9.71 & 7.76 & 11.04 & 11.24 & 7.80 & 16.70 \\
SH Land & 5.88 & 6.70 & 9.53 & 8.95 & 9.70 & 10.82 & 8.60 & 13.00 \\
\hline
\end{tabular}

Title Page

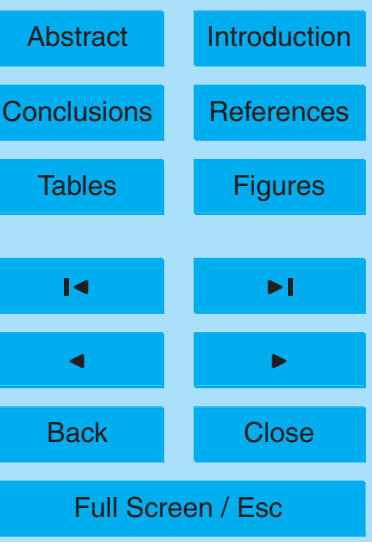

Printer-friendly Version

Interactive Discussion 


\section{ACPD}

7, 14295-14330, 2007

\section{Aerosol-cloud interactions in the NASA GMI}

Table 6. Annual means of the simulated aerosol first indirect effect $\left(\mathrm{W} \mathrm{m}^{-2}\right)$ for all cloud droplet formation parameterizations and meteorological fields. Averages for the Northern $(\mathrm{NH})$ and Southern (SH) hemispheres, and land and ocean averages are also included.

\begin{tabular}{lccccc}
\hline Simulations (MetField_DropParameterization) & Land & Ocean & $\mathrm{NH}$ & $\mathrm{SH}$ & Global \\
\hline DAO_FN & -2.59 & -0.81 & -1.85 & -0.55 & -1.23 \\
DAO_BL & -2.08 & -0.95 & -1.62 & -0.74 & -1.18 \\
FVGCM_FN & -2.90 & -1.06 & -2.15 & -0.79 & -1.48 \\
FVGCM_BL & -2.27 & -1.01 & -1.77 & -0.79 & -1.28 \\
GISS II'_FN & -2.17 & -0.63 & -1.50 & -0.47 & -1.00 \\
GISS II'_BL & -1.85 & -0.74 & -1.38 & -0.52 & -0.99 \\
\hline
\end{tabular}

Title Page

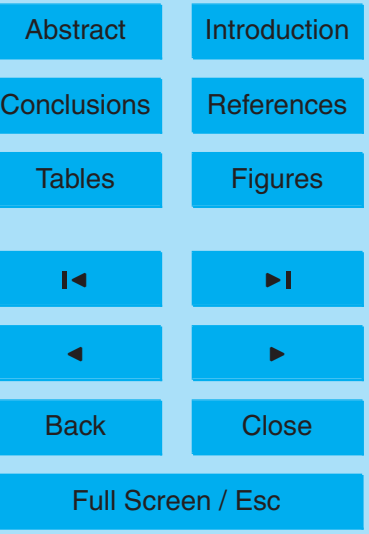

Printer-friendly Version

Interactive Discussion 


\section{ACPD}

7, 14295-14330, 2007

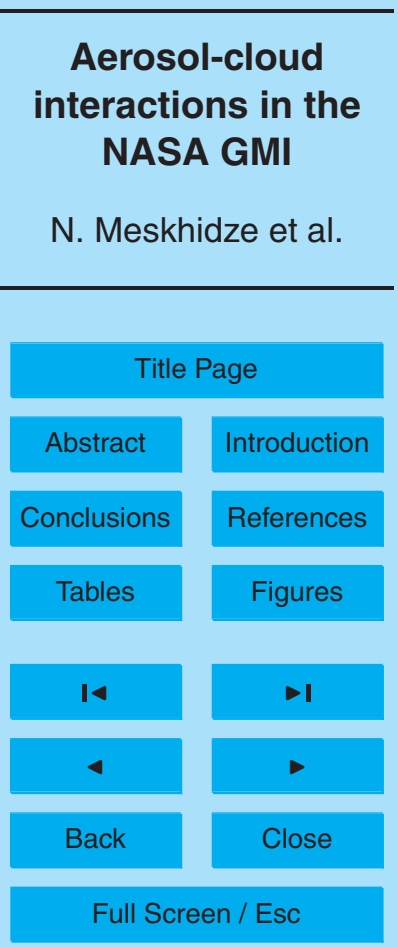

Fig. 1. Algorithm for calculating the indirect forcing scaling factor, F, used to compute indirect forcing in all the calculations of this study

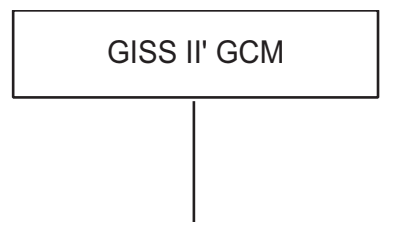

FN Activation Parameterization

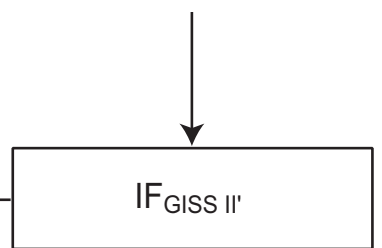

$F=\frac{I F_{G I S S ~ I I '}}{I_{F_{G M I}}}$
Printer-friendly Version

Interactive Discussion 


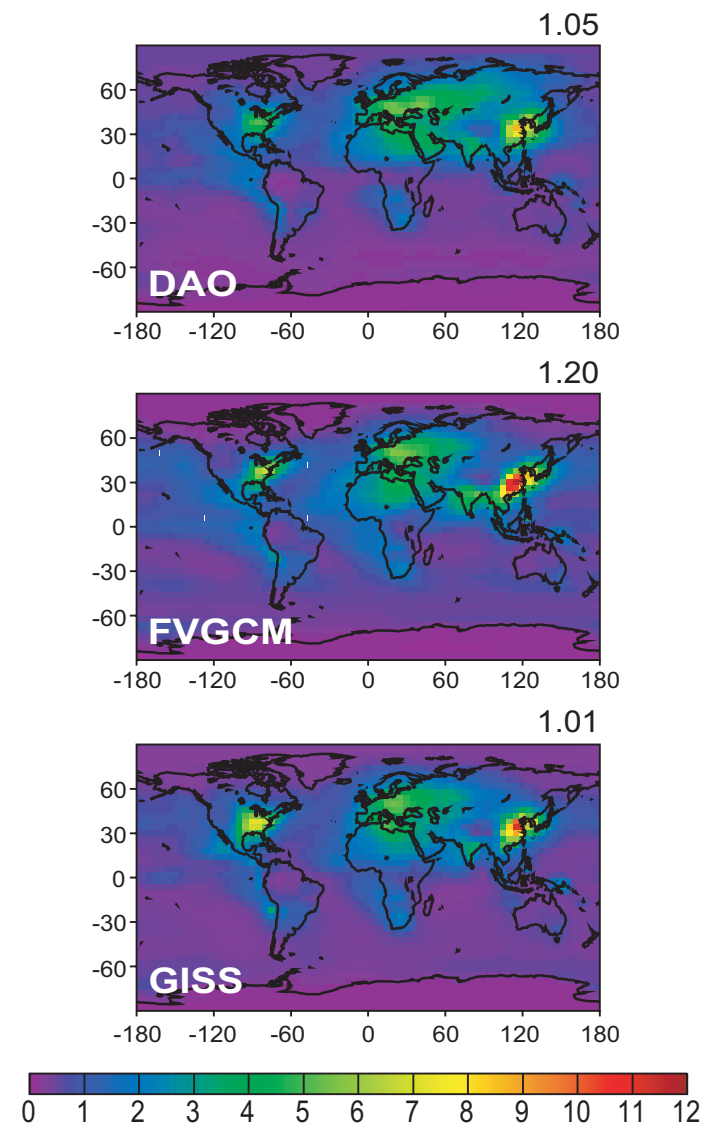

Fig. 2. Annually-averaged sulfate $\left(\mu \mathrm{g} \mathrm{m}^{-3}\right)$ distributions at the surface level for the meteorological datasets of NASA Data Assimilation Office (DAO), NASA finite volume GCM (FVGCM) and the Goddard Institute for Space Studies version II' (GISS) GCM. The global average value is shown in the upper right hand corner of each panel.

\section{ACPD}

7, 14295-14330, 2007

Aerosol-cloud interactions in the NASA GMI

N. Meskhidze et al.

\section{Title Page}

Abstract

Conclusions

Tables

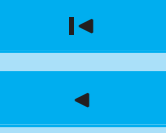

Back
Introduction

References

Figures

$>1$

$>$

Close
Full Screen / Esc

Printer-friendly Version

Interactive Discussion 


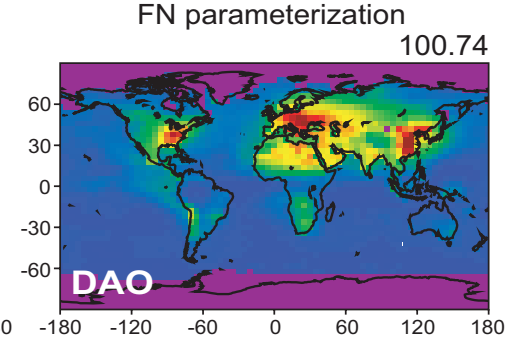

\section{ACPD}
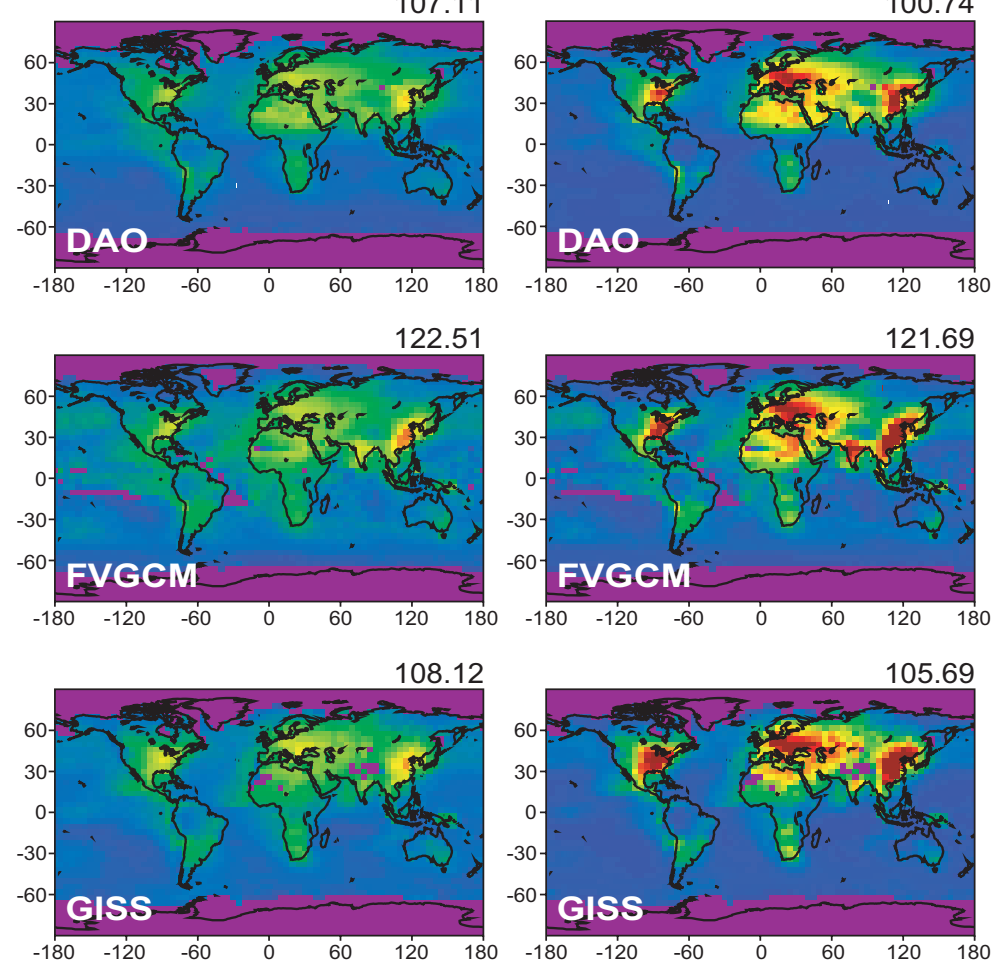

$0 \quad 50100150200250300 \quad 350 \quad 400 \quad 450 \quad 500 \quad 550>$

\section{Aerosol-cloud interactions in the NASA GMI}

N. Meskhidze et al.

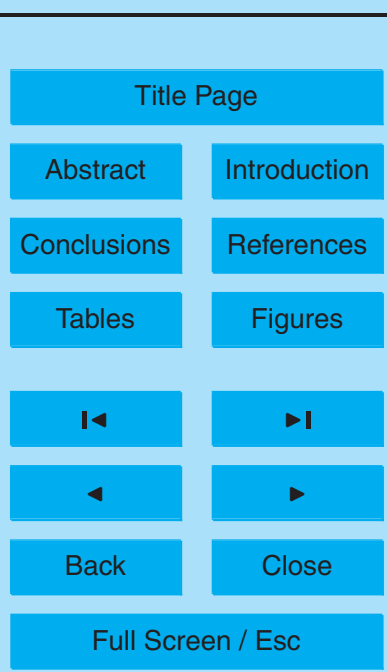

Fig. 3. The global distribution of yearly averaged GMI model simulated cloud droplet number

Printer-friendly Version concentration $\left(\mathrm{cm}^{-3}\right)$ for the schemes of Boucher and Lohmann (1995) and Fountoukis and Nenes (2005) and the meteorological datasets from NASA Data Assimilation Office (DAO), Interactive Discussion NASA finite volume GCM (FVGCM) and the Goddard Institute for Space Studies version II' (GISS) GCM. The global average value is shown in the upper right hand corner of each panel. 14327 

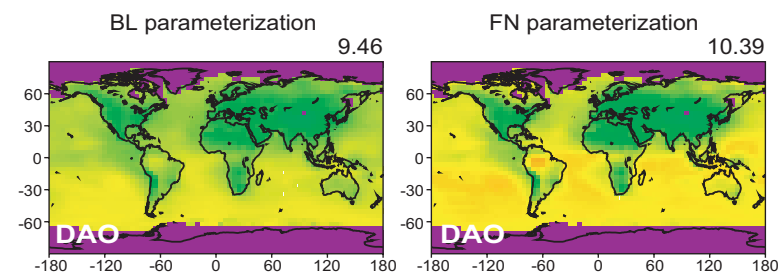

\section{ACPD}
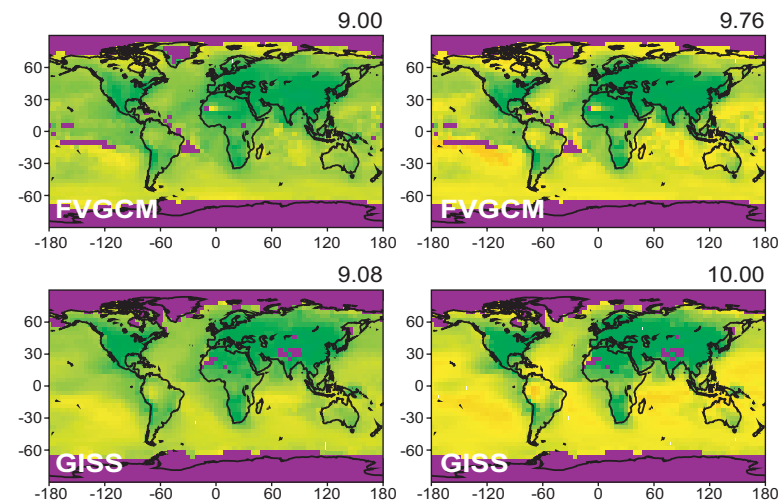

10.00

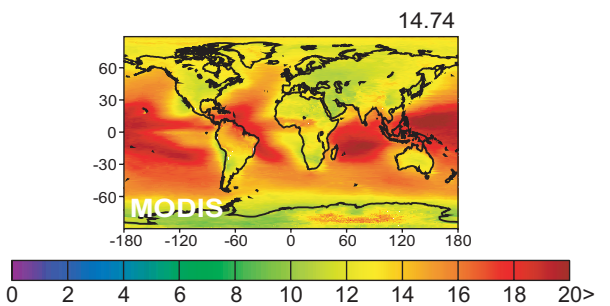

\section{Aerosol-cloud interactions in the NASA GMI}

N. Meskhidze et al.

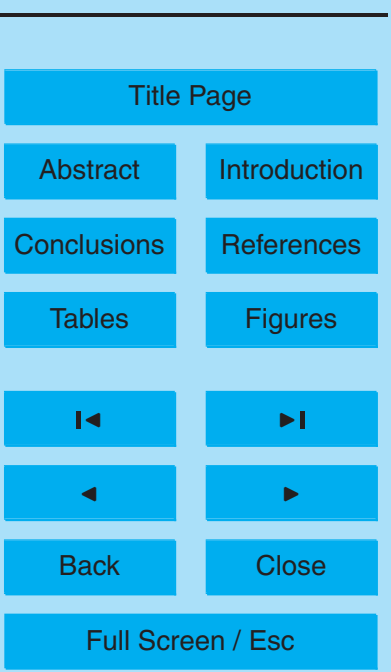

Fig. 4. Global distribution of cloud droplet effective radii: Annual averages for the schemes of Boucher and Lohmann (1995) (left panel) and Fountoukis and Nenes (2005) (right panel) and seven-year average (April 2000-December 2006) satellite retrievals form MODIS platform (bottom panel). The global average value is shown in the upper right hand corner of each panel. 

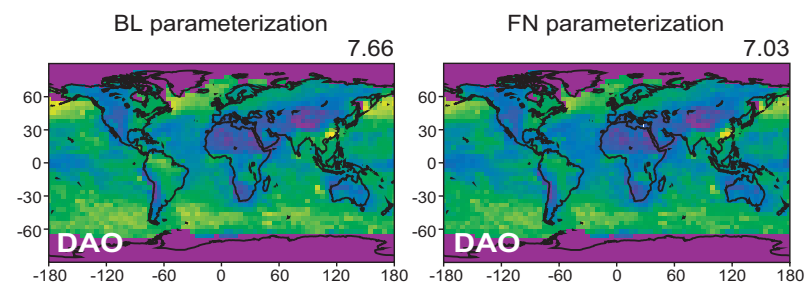

\section{ACPD}

7, 14295-14330, 2007
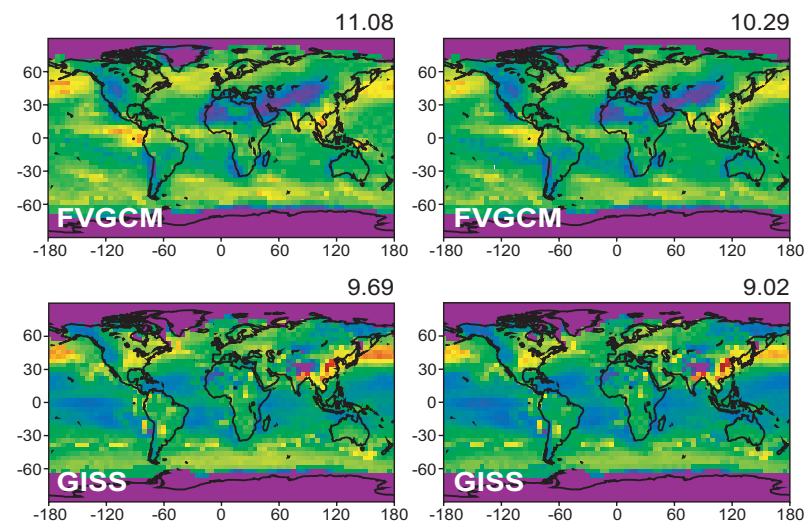

9.02

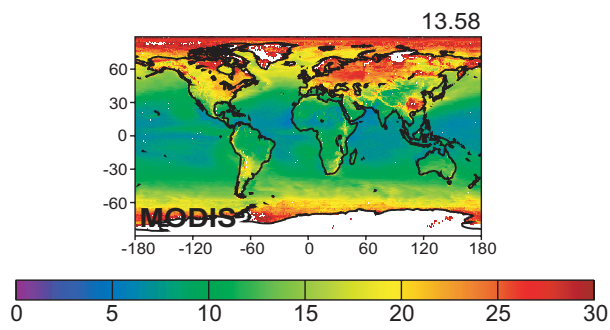

3.58

Fig. 5. Global distribution of cloud optical thickness: Annual average for the schemes of Boucher and Lohmann (1995) (left panel) and Fountoukis and Nenes (2005) (right panel) and seven-year average (April 2000-December 2006) satellite retrievals form MODIS platform (bottom panel). The global average value is shown in the upper right hand corner of each panel.

\section{Aerosol-cloud interactions in the NASA GMI}

N. Meskhidze et al.

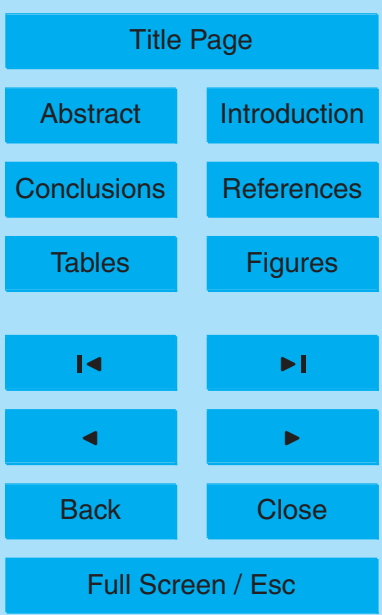

Printer-friendly Version

Interactive Discussion 
BL parameterization

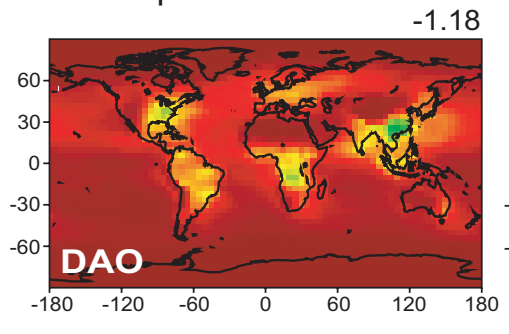

8

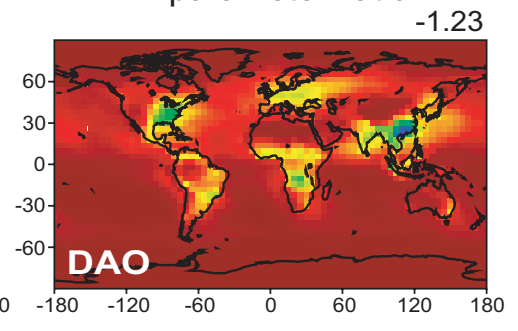

$-1.48$
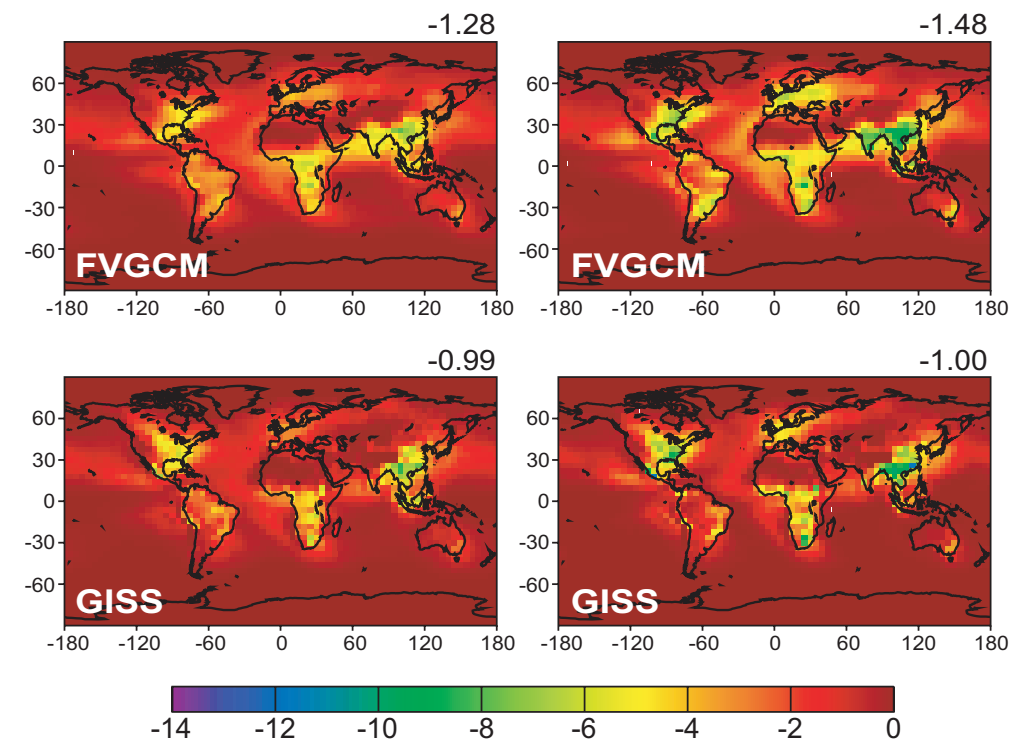

Fig. 6. Simulated annual mean first aerosol indirect forcing $\left(\mathrm{W} \mathrm{m}^{-2}\right)$ for the schemes of Boucher and Lohmann (1995) (BL), Fountoukis and Nenes (2005) (FN) and the meteorological fields from NASA Data Assimilation Office (DAO), NASA finite volume GCM (FVGCM) and the Goddard Institute for Space Studies version II' (GISS) GCM. The global average value is shown in the upper right hand corner of each panel.

\section{ACPD}

7, 14295-14330, 2007

\section{Aerosol-cloud interactions in the NASA GMI}

N. Meskhidze et al.

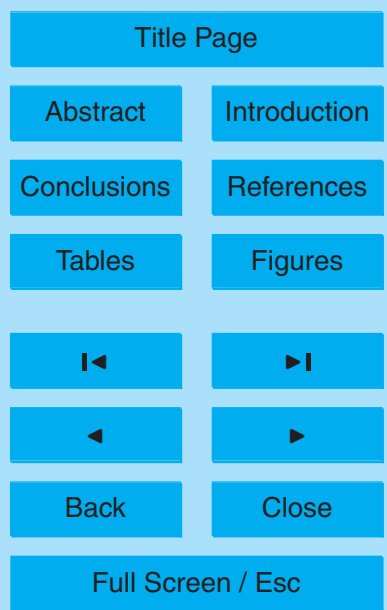

Printer-friendly Version

Interactive Discussion 